\title{
Rosicrucianism Challenged: Early Debates
}

Once published, the Rosicrucian manifestos and their proponents attracted much criticism from all quarters of Europe, and from all corners of the intellectual world. ${ }^{1}$ Chemists, physicians, and theologians alike were shocked and outraged by these heterodox texts. Scholars immediately penned their critiques, while representatives of several universities and courts launched investigations into individuals they suspected of Rosicrucianism. While Haslmayr was forced to row the galleys, arguments for and against the manifestos continued apace. In a study of Rosicrucianism, an analysis of the movement through the eyes of its most fervent adversaries is appropriate, because only by also studying its critics is one able to identify all the salient points and novelty of the Rosicrucian claims.

A good method for an analysis of anti-Rosicrucianism is to tackle the opposing arguments involved in polemical constellations, and to investigate key discussions between anti-Rosicrucian scholars and Rosicrucian apologists. One of the best-known critics of the Rosicrucian manifestos was the Lutheran physician and alchemist Andreas Libavius (ca. 156o-1616). His alchemical writings and anti-Paracelsian sentiments have received appropriate attention in the recent available historiography, but his fierce attacks on the Rosicrucian fraternity and their followers still deserve proper investigation. ${ }^{2}$ Libavius' criticism

1 Kahn, "The Rosicrucian Hoax in France," for more detail on key participants such as Gabriel Naudé, Jean Roberti, and François Garasse. On anti-Rosicrucianism in general, see, for example: Schick, Das ältere Rosenkreuzertum; Peuckert, Das Rosenkreutz; Yates, The Rosicrucian Enlightenment.

2 On Libavius, see: Thorndike, A History of Magic and Experimental Science, vol. 2, 244-270; on Libavius in relation to alchemy and Paracelsianism, see: idem, A History of Magic and Experimental Science, vol. 6, 238-253; Partington, A History of Chemistry; Multhauf, "Libavius and Beguin"; Hannaway, The Chemists and the Word; Moran, "Medicine, Alchemy, and the Control of Language"; idem, Andreas Libavius; idem, "Andreas Libavius and the Art of Chymia"; Debus, The Chemical Philosophy, 169-173, 215, 217; Newman, Atoms and Alchemy, 66-81; Gilly, "La 'quinta colonna' nell'ermetismo: Andreas Libavius"; Forshaw, "'Paradoxes, Absurdities, and Madness'”; on Libavius' alchemy and atomism, see: Lüthy, "The Fourfold Democritus on the Stage of Early Modern Science," 475-479; Newman, Atoms and Alchemy, 66-84; Moreau, "Eléments, atomes et physiologie," 179-232; on Libavius and Rosicrucianism, see: Schick, Das ältere Rosenkreuzertum, 206-212, 258-264; Peuckert, Das Rosenkreutz, 96-97, 102-103, 116-120; Yates, The Rosicrucian Enlightenment, 69-72; Gilly, Johann Valentin Andreae, 83-86; Shackelford, A Philosophical Path for Paracelsian Medicine, 337-340. 
of the movement was not much later vigorously refuted by the English neoPlatonist philosopher, astrologer, and physician Robert Fludd (1574-1637), who is well known for his Rosicrucian sympathies. ${ }^{3}$ In 1617 , one year after Fludd's written defence of Rosicrucianism, another Rosicrucian opponent, Friedrich Grick (dates unknown), published a ruthless attack on the fraternity. While not as famous a figure as Libavius, and not yet studied comprehensively, he belongs to the few well-known names of anti-Rosicrucianism. ${ }^{4}$ Grick's attack soon received a response from Daniel Mögling, whom we have encountered in the previous chapter.

In the texts of these four authors about the Rosicrucian phenomenon, the arguments pro and contra the Rosicrucian manifestos are best brought to light, revealing what was most at stake for these defenders and detractors of the Rosicrucian writings and the ideas expressed in them. How and to what extent did the general reformation play a role in their writings?

Alongside these debates, universities and courts responded formally to Rosicrucianism. What urged institutions to officially suppress or contain the ideas and sympathies of their members, and how do these formal responses compare to the informal critiques of Rosicrucian opponents? By way of conclusion of this chapter, the early modern debates over Rosicrucianism will briefly be compared to several official investigations.

Libavius publically rejected the Rosicrucian manifestos in the Analysis of the Confession of the Rose Cross (1615). ${ }^{5}$ In response, the following year Fludd penned a refutation of Libavius' arguments in his defence of the brotherhood, the Short Apology (1616). ${ }^{6}$ Shortly after the publication of Libavius' second blast, the Well-intentioned Considerations (1616, ten times as large as his

3 On Fludd, see, for example: Schick, Das ältere Rosenkreuzertum, 257-270; Hutin, Robert Fludd (1574-1637). Alchimiste et philosophe rosicrucien; Godwin, Robert Fludd. Hermetic Philosopher and Surveyor of Two Worlds; Debus, Robert Fludd and his Philosophicall Key; idem, The Chemical Philosophy, 205-293; Huffman, Robert Fludd and the End of the Renaissance. Fludd also used two pseudonyms: Rudolfus Otreb and Joachim Frizius.

4 On Grick, see:Waite, Real History, 258; Schick, Das ältere Rozenkreuzertum, 230-235; Peuckert, Das Rosenkreutz, 135-144, 165, 361-367, 390, 392; Gilly, "Iter Rosicrucianum," 63; idem, Cimelia Rhodostaurotica, 78-79; Neumann, "Olim, da die Rosen Creutzerey noch florirt"; McIntosh, The Rosicrucians, 34-35; Keller, Knowledge and the Public Interest, 70-79.

5 Libavius, Analysis Confessionis Fraternitatis de Rosea Cruce.

6 Fludd, Apologia Compendiaria (1616). 
1615-refutation), he passed away, and he probably never had a chance to read Fludd's reply.7 Despite his opponent's death, Fludd published an enlarged version of his defence in his Apologetic Tract (1617). ${ }^{8}$ Although the Apologetic Tract has received some attention from historians, Fludd's Short Apology still awaits a careful analysis, even though this was his first clear response to Libavius' criticism. ${ }^{9}$ In order to analyse Libavius' and Fludd's arguments for and against the fraternity in a polemic context, it is best to examine the two writings where the second was a clear response to the author of the first, the Analysis and the Short Apology.

\section{Libavius: Protecting Faith and Learning}

By the time of writing his Analysis, Libavius was an established scholar. He had studied at the universities of Wittenberg and Jena, and had matriculated in medicine at the University of Basel in the 1580 . After graduation, he worked as a teacher at several schools and universities, and as a physician in Rothenburg from 1591 onwards. The topics about which he wrote were varied and included, among others, medicine, history, botany, zoology, and chemistry. His most famous work was his Alchemia (1597), putatively the first textbook on chemistry, which was followed by a second, revised edition under the title Alchymia in 1606. Libavius was further involved in numerous disputes and polemics, in which he openly and pointedly criticised his opponents. ${ }^{10}$ For example, in his Consideration of the New Philosophy (1615) he attacked many physicians for belonging to the so-called Paracelsian movement, which had developed mostly outside of the universities. Among those were most famously Joseph DuChesne (Quecertanus, ca. 1546-16o9), Petrus Severinus (1542-16o2), Oswald Croll, and the editor of Crolls' Basilica Chymica, Johann Hartmann (1568-1631).11 Hartmann, who had provided the Danish physician and Rosicrucian critic Ole Worm (1588-1655) with a copy of the Fama, ${ }^{12}$ was notably the first professor of

7 Libavius, Wohlmeinendes Bedencken (1616).

8 Fludd, Tractatus apologeticus integritem societatis de rosea cruce defendens (1617).

9 Idem, Apologia Compendiaria, 7. A brief analysis of Fludd's defence can also be found in: Moran, Andreas Libavius, 242-246. Schick, Das ältere Rosenkreuzertum, 257-270, focuses on a German translation of the later Apologetic Tract and on later texts; Debus, The Chemical Philosophy, 216-224 discusses only the Apologetic Tract.

10 Hubicki, "Libavius, Andreas," in Dictionary of Scientific Biography, vol. viII, 309-310.

11 Libavius' critical works of Paracelsianism include: Examen philosophiae novae (1615); Exercitatio Paracelsica nova (1615); Analysis Confessionis (1615); Wohlmeinendes Bedencken (1616). Libavius also criticised the views of Heinrich Khunrath; on this, see: Forshaw, "'Paradoxes, Absurdities, and Madness," esp. $77 \mathrm{ff}$. 
chymiatria when he acquired a position in chemical medicine in 1609 at Moritz von Hesse-Kassel's University of Marburg — a fact that Libavius particularly deplored as it meant that Paracelsian ideas were now being taught even at a university. ${ }^{13}$

Although primarily known for his alchemical and medical writings and his criticism of Paracelsianism, Libavius was not unfamiliar with subjects of a theological nature - an aspect of his work that merits further investigation. ${ }^{14}$ He was a Lutheran who belonged to the academic establishment and moved primarily in Lutheran academic circles. The universities at which he had studied, Wittenberg and Jena, were Lutheran, and the same is true of the cities in which he took up work, including Ilmenau, Rothenburg, and Coburg. The gymnasium in Coburg, where Libavius worked as rector from 1607 onwards, was especially characterised by its orthodox Lutheranism, which is why it was never granted the status of university by Rudolph II. ${ }^{15}$ Libavius also published religious and anti-Catholic writings under the pseudonym Basilius de Varna (an anagrammatic representation of Andreas Libavius). In his Dialectic Analysis of the Colloquium of Regensburg (1602), for example, he vehemently argued against the Roman confession. The text was a response to the Regensburg Colloquium on religious matters held between Lutherans and Catholics under the examining eyes of the Lutheran Count Philip Ludwig of PalatinateNeuburg (1547-1614) and the Catholic Duke Maximilian I, Elector of Bavaria $\left(1573^{-1651)} \cdot{ }^{16}\right.$ As a devout Lutheran, Libavius extolled the authority of Scripture in his text and argued against anyone who sought to diminish its authority. ${ }^{17}$

philosophica summa (1619): "Sed unicus, quod sciam, tum extitit Andreas Libavius Theologus \& Medicus celeberrimus qui primum fratrum impetum retundere quasi aggressus est," cited in: Shackelford, A Philosophical Path for Paracelsian Medicine, 339.

13 Moran, Andreas Libavius, 225-226, 232.

14 See, for example: Hubicki, "Libavius, Andreas," in Dictionary of Scientific Biography, vol. vilI, 309-310; Moran, Andreas Libavius, $315 \mathrm{ff}$.

15 Hubicki, "Libavius, Andreas," in Dictionary of Scientific Biography, vol. viII, 309. On Libavius' time as rector, see: Moran, "Medicine, Alchemy, and the Control of Language," 137-139.

16 Libavius [Basilius de Varna], Analysis dialectica colloquii Ratisbonensis (1602); Moran, Andreas Libavius, 111-112. On this colloquium, see ibid., 105-111. Libavius' adherence to the Lutheran confession is also evident from his criticism of Oswald Croll; see, for example, the first sections on Croll in: Libavius, Examen novae philosophiae, $18-87$, in which Libavius analysed Paracelsian and Crollian ideas not only from a medical and alchemical perspective, but also in relation to biblical passages and orthodox Lutheran views, such as the impossibility of earthly perfection.

Moran, Andreas Libavius, 116. 
His Lutheranism is also instrumental in his attack on the Rosicrucians. ${ }^{18}$ His Analysis casts no doubt on the existence of either the fraternity or of their proclaimed father, Christian Rosencreutz. Libavius understood the manifestos as serious mission statements from a brotherhood consisting of several members, working in a secret place in Germany. What worried Libavius were the objectives of the Rosicrucian fraternity as conveyed in their manifestos. He took seriously their alleged prophetic nature, and so he investigated these writings as prophecies. For this, he found inspiration in warning words from the Bible. Recalling Paul's words that a time will come when some will not follow the Christian doctrine, but fables instead, ${ }^{19}$ Libavius wondered whether such was the nature of the Rosicrucian manifestos: did they not merely tell fabricated stories like evil spirits rather than prophesy the truth? To Libavius, Scripture was the ultimate authority for truth, and therefore true prophecies had to be consistent with biblical accounts. ${ }^{20}$ To prove his allegations against the Rosicrucians, he structured his text into 76 paragraphs in which he discussed thirteen Rosicrucian claims ("argumenta") about their fraternity, philosophy, and mission. ${ }^{21}$ "The brethren," he wrote, "warn that we should not consider [their arguments] for fictions," but Libavius was not so easily convinced and instead tested their veracity in relation to religion, academic reform, and Paracelsian magic. ${ }^{22}$

18 Wels mistakenly argues that Libavius only cared for the development of naturalphilosophical investigations and not for religious matters: Wels, "Die Frömmigkeit der Rosenkreuzer-Manifeste," 183.

192 Timothy 4:3-4: "For a time will come when they will not endure sound doctrine; but after their own lists shall they heap to themselves teachers, having itching ears. And they shall turn away their ears from the truth, and shall be turned unto fables."

20 Libavius, Analysis Confessionis, 3: "Vnde et Apostolus Paulus annunciato eugelio [sic] de Christo, Philosophis videbatur noua quaedam auribus eorum ingerere de daemonibus nouis, noua quaedam doctrina [...]. Noui quid nostrorum temporum Theologis et Philosophis a Societate Roseae Crucis proponitur. It cuisusmodi sit, non pruritu nouitatum in doctrina Christiana, de quo loquitur Paulus 2 Tim. 4.3. [...]. perpendendum est, sed iuxta regulam Paulinam 1 Thessal.5.20 'prophetias nolite spernere. Omnia probate, quod bonum est, tenete'. Et Johannis 1.Joh.4.1. 'Nolite omni spiritui credere, sed probate spiritus, si ex Deo sint. Nam multi Pseudo-prophetae exierunt in mundum'. Sunt et vaticinia grauissima de apostasiis vltimorum temporum, de charitate frigida, et fide tam tenui, vt vix possit in terris inueniri. Non ergo extinguemus spiritum, neque spernemus prophetiam ante probationem; sed faltem quid rei sit, confiderabimus." 1 Thessalonians 5:20-21: "Despise not prophesyings. Prove all things; hold fast that which is good." 1John 4:1: "Beloved, believe not every spirit, but try the spirits whether they are of God: because many false prophets are gone out into the world."

21 These arguments were followed by another 20 , of which an overview can be found in: Libavius, Analysis Confessionis, 17-18.

Libavius, Analysis Confessionis, 3: "Monent fratres, ne pro figmentis habeamus ea, quae in 


\section{A General Reformation}

To Libavius, it was precisely the Rosicrucian call for an earthly general reformation that was the most central, radical, and refutable aspect of the manifestos, and he referred to it even in the first sentence of his Analysis:

The society predicts a general reformation after the example of an earthly [reformation] shortly before the end of the world (which some say to take place in the year 1623 , others in 1643 , others in 1656 , others in 1670 , etc.). ${ }^{23}$

This sentence provides us with a snapshot of what Libavius considered most troubling: a comprehensive reformation, which would take place on earth and come to pass before the Last Judgement. In numerous places throughout the text, he returned to the brethren's general reformation and problematised it from multiple perspectives. ${ }^{24}$

Libavius criticised the fallibility of the Rosicrucian general reformation, and argued that the brethren's prophetic predictions of the future lacked the detail and evidence needed to substantiate their claims. He lamented the brethren's assertion that:

the total reformation has its origin from God, which is indicated both by the harmonious union of the world, and by the appearance of the new stars in Serpentarius and Cygnus, which [for them] is a testimony concerning the divine will, and [concerning] sublime things and things of great moment. ${ }^{25}$

Libavius did not discuss these astronomical events as such, but considered the Rosicrucians' claims to be lacking in detail, argument, and precision, and regarded them as unconvincing: "This argument is very obscure. And so it is to be explained what this instauration and renovation is; then who can learn this from the new stars and from the characters of the great world?"26

Fama sunt prodita, quaeque iam in Confessione proponuntur, cum nec nugae leuiculae sint, nec ex opinione vana fratrum profluant [...]."

23 Ibid., 2: "Societas generalem reformationem ad exemplum terrenae paulo ante mundi finem (quem alii dicunt futurum esse An. 1623. alij 1643: alij 1656: alij 167o etc.) praedicit."

24 Cf. ibid., 2-6, 8-12, 17, 21-23, 25, 28.

25 Ibid., 3: "[...] verum ex Deo tota reformatio ortum habeat, id quod tum harmonica mundi conciliatio indicet, tum novarum stellarum apparitio in Serpentario et Cygno, quae sit testimonium de voluntate divina, deque sublimibus et magni momenti rebus, etc." For the first part of this passage, see above, n. 22 .

26 Libavius, Analysis Confessionis, 3: "Hoc argumentum valde est obscurum. Itaque 
The brethren claimed authority over such matters, but Libavius questioned and problematised them: $: 27$ "When were your characters impressed on the world?" 28 And if truly such a universal reformation were to occur, as the brethren had professed, Libavius wondered who would be granted such an "integrity of Paradise." Solely the Rosicrucian society, or would it also extend beyond their fraternity? Would there be a reform only in their fatherland, or in the entire world? In one place, Libavius argued, the Rosicrucians professed that such enlightenment was selective, while elsewhere they argued that the reformation was universal. ${ }^{29} \mathrm{He}$ presumably referred to the promise contained in the Confessio that everyone is granted the right "to behold, read and thereafter to comprehend these great [celestial] letters of God," whereas the manifesto taught earlier that "the Book of Nature is opened wide before the eyes of all, even though few can either read or understand it" - which in Libavius' eyes contradicted the previous statement. ${ }^{30}$ The brethren, as Libavius pointed out time and again, were ambiguous and contradicted themselves. They are "seen to write falsities and deceive the world with empty hope."31

This was neither a substantive rejection of Rosicrucianism, nor was it Libavius' foremost criticism. The announcement of a general reformation was, in his view, a religious claim, and for that reason Scripture had to be the foundation for any legitimate Rosicrucian expression—but the brethren had made no references to the biblical account. Throughout his text, and implicitly invoking the Lutheran sola scriptura, Libavius argued that the Rosicrucian plan for a general reformation, as made public in their manifestos, did not agree with the plan of God as communicated in Scripture.

explicandum est, quae sit ista instauratio et renouatio: Deinde qui possit id ex stellis nouis, et mundi magni characteribus disci."

27 Ibid., 4: "Quod aut attinet ad nouas stellas, et characteres, qua fide probatis vestras ex eis praedictiones? Video vos affere, 'utiles esse quidem ad id arcanas scripturas et characteres, sed licet magnus liber naturae omnibus pateat, tamen paucos esse, qui illum possint legere.' Sensus est: a vobis ista singulariter in mundi libro lecta esse, utpote illuminatis."

28 Ibid., 5: "Vestri characteres quando impressi sunt mundo?"

29 Ibid., 9: "Si reditura est integritas Paradisi, sane immunitas erit a molestiis, sed tunc nihil intererit, siue in societate sis, siue extra eam. Si autem ea non erit vniuersalis, sed tantum particularis, eos attinens, qui sunt membra societatis, videant de suo Christianismo."

30 Confessio, 52 , 55. Cf. above, sections 1.2. and 1.3.

31 Libavius, Analysis Confessionis, 10: "quo argumento quis vereatur, ne et vos sitis foris, qui videmini falsitates scribere, et inani spe mundum lactare, nisi fortassis haec est mens vestra, quod non totus orbis sit futurus Paradisus, sed tantum vestra patria [...]." Libavius probably referred to: Confessio, 45: "Caeterum ut plerumque in eo ipso loco, ubi nova lues exsurgit, Natura remedium aperit, ita inter tantos Philosophiae paroxysmos, patriae nostrae satis idonea, imo ad sanitatem unica media succrescunt, per quae revalescat et nova, vel renovata, mundo renovando appareat." 
Libavius' criticism of the Rosicrucian general reformation in his Analysis was, to a large extent, directed at the Rosicrucians' apocalyptic expectations and millenarian imagery. According to Libavius, the brethren had wanted their general reformation to take place in a future age of felicity. He specified that they had claimed that the world was yet to be renewed, that it was at the end of the period and would rush back towards its beginning. ${ }^{32}$ Libavius granted that renewal was announced in the gospel, and he quoted Isaiah 43:19, which cites the words of the Lord: "See I make everything new." But, so Libavius explained, the Lord's renewal did not refer to the new period of which the Rosicrucians prophesied, because it was "previously fulfilled by the Gospel preached by the Son." ${ }^{33}$ With no announcement in biblical prophecies of another, second, renewal on earth, the belief that any such event could take place was not tenable. ${ }^{34}$ Addressing the manifestos' authors directly, Libavius argued that "about your restitution before the end of the world we have nothing in the prophecies, but rather the contrary."35 He claimed that only after Christ's Second Coming could there be a restitution of the world; the millennium lay not in the future, but presumably, as Luther had taught, in the past.

Even if Scripture had foretold that there should be a thousand-year Golden Age in the future, as Libavius suspected was the Rosicrucians' conviction, he believed that the general reformation the Rosicrucians envisioned would still not take place. The Bible taught that such a millennium would be followed by a short period under the rule of Satan. But if that were the case, Libavius commented, "the reformation of the world will not be universal, but only a small group of saints will remain," as was explained in the Book of Revelation 20. Even chiliasts would have to agree that Satan will rule after their proclaimed millennium and that perfection before the end would neither be universal nor

32 Libavius, Analysis Confessionis, 3: "Pag. 55. Mundus ad finem perductus absoluta periodo festinat ad principium. P. 57. Mundus iam debet renouari." Cf. Confessio, 43: "Jehova est qui mundo labascente, et propemodum periodo absoluta, ad principium properante Naturae ordinem invertit."

33 Libavius, Analysis Confessionis, 3: "Nouimus quidem ex Esa.43.v.19. Devm dicere: 'Ecce facio omnia noua': sed hoc pridem impletum est Euangelio per Filium praedicato." Cf. Isaiah 43:19 (New International Version): "See I am doing a new thing! Now its springs up; do you not perceive it? I am making a way in the wilderness, and streams in the wasteland." Cf. Libavius, Analysis Confessionis, 21: “'Credimus enim, restitutionem omnium bonorum, atque insuper etiam gloriae acceßionem, et vitam aeternam Electorum Dei'. At non ante finem mundi nihil tale fore, persuasum habemus, quia contrarium est in Prophetiis non mendacibus $[\ldots]$."

35 Ibid., 4: "At de vestra restitutione ante finem mundi nihil habemus in vaticiniis, sed contrarium potius." 
complete. According to Libavius, there could neither be perfection on earth "nor will the bad be removed before the arrival of Christ."36

The promise of earthly perfection as stated in the manifestos was a claim perhaps even more problematic to Libavius than chiliasm, which was at least partly grounded in Scripture. Contradicting such claims, Libavius argued that "Christ has indicated to us signs of the world's future destruction," and "he has left behind nothing of your paradise-like happiness." 37 Hopeful expectations of earthly perfection were condemned in official Lutheran writings. ${ }^{38}$ Likewise for Libavius, it was only the final tribulations that could be expected: "The entire world is placed in wickedness, and the holy writings promise no beatitude to the militant Church, but they preach about the greatest evils." 39

Libavius explained that "the perfect restitution of everything is not expected in time, but after time." 40 Whereas the Rosicrucian manifestos had promised the return of original conditions to the world, and therefore the restoration of the state of Paradise,${ }^{41}$ Libavius confirmed the Lutheran view that a restitution of paradise-like perfection was to take place when the righteous are allowed to enter the New Jerusalem. It could only be instigated by divine intervention and not by man or the Rosicrucians specifically, as the manifestos predicted. Commenting on Acts 3:21, Libavius stated:

36 Ibid., 21: "An vos Chiliastarum sententiam sequimini mille quidem annos fore aureum seculum, posteaque Sathanam liberatum seducturum. Quos? 'Gentes, Gog, Magog,' Si ita est, vniuersalis non erit mundi reformatio, tantum paruus grex sanctorum restabit. Apoc 2o. Imo hi, qui cum 'Christo' regnaturi dicuntur annos mille, vers. 4. introducuntur decollati. Si vers. 5. Qui post Paradisum vestram sanctorum in terra erit ciuitas? Non autem desituros esse sanctos ante iudicium, indicat 'Paulus' 1. Thess.4.17. Sed nec mali tollentur ante aduentum 'Christi', Matth.24.3o.\& sequent. 'Millenarij' non huius seculi vitam, sed alterius intellexerunt."

37 Ibid., 5: "Saluator nobis indicauit signa mundi perituri. Matth. 24, et alibi. Vestrae felicitatis Paradisiacae nulla reliquit qui tamen omnia a Patre audita exposuit Joh 15.15."

38 Cf. above, section 1.3.

39 Libavius, Analysis Confessionis, 9: "Totus mundus in maligno positus est, et sacrae literae nihil beatitudinis Ecclesiae militanti promittunt, sed de maximis malis concionantur."

40 Ibid., 4: "Verum restitutio omnium perfecta, non in seculo expectanda est, sed post seculum."

41 Cf. ibid., 4: “'Revocandus et mundus ad statum Paradisi ante lapsum [...].' Pag 69. Bene obseruandum est, \& singulis significandum, quod Deus certo \& omnino devreuerit mundo ante interitum, qui paulo post continget, plane, 'talem veritatem, lumen, vitam, \& gloriam conferre', qualem primus homo Adam in Paradiso amisit." 
we know there will be a time of the restitution of everything: but through Christ returning from heaven to the Judgement, and this restitution will begin after the arrival of the visible Elijah or of John the Baptist $[\ldots]{ }^{42}$

Interpreting John 16:20- "Your sorrow shall be turned into joy"-Libavius insisted that this joy would neither be man-made nor granted in the present world; and so he remarked: "In this life, then? Not at all: but in another, not a life before the [Last] Judgement which you dream up on account of Paracelsus, but a life which Christ grants to his elected after the Final Day."43 The sins of the first humans had resulted in the Fall, and because of man's sin God would not want the world freed from calamities, and so the Last Times will be characterised by punishment. ${ }^{44}$

Libavius further noted the Rosicrucians' suggestion that the final age was to be accompanied by complete wisdom, which can be seen as equally unorthodox. While referring to biblical verses, he claimed that "[w]e believe that after the terrestrial time among the elect, there will be such a perfect restoration of the divine image as a sublime state of glory beyond our reckoning," but not here on earth. Human beings may acquire the wisdom of the gospel, but no complete Adamic wisdom could be expected before the Last Days. The idea, voiced in the manifestos and by early Rosicrucian followers, that humans on earth may already be granted Adamic knowledge, was according to Libavius a dangerous illusion. ${ }^{45}$ So he argued that "the world cannot receive the spirit

42 Ibid., 4: "Videte fratres de Rosea Cruce, qui cum Verbo Dei vestra explicatio possit consistere. Scimus Act.3.v.21. fore tempus $\alpha \dot{\pi} 0 x \alpha \tau \alpha \sigma \tau \dot{\alpha} \sigma \varepsilon \omega \varsigma \pi \dot{\alpha} v \tau \omega \nu$ seu restitutionis omnium: sed Christo a coelo redeunte ad iudicium et eam restitutionem inchoari ab aduentu secundum apparentis Eliae seu Iohannis Baptistae, Matt. 17.11 consummari aditu gloriae, quod \& tempus refrigerii iam manifestatis filiis Dei in gloria coelesti. Actor.3.20. \& Matth.19.28 dicitur." Cf. Confessio, 53-54: "Deum mundo haud longe post interituro, reddendam veritatem, Lucem et dignitatem decrevisse [...]."

43 Libavius, Analysis Confessionis, 9: "Joh.16.v.20 'Amen, Amen, dico vobis: Plorabitis et flebitis vos: mundus autem gaudebit: vos contristabimini. Sed tristitia vestra vertetur in gaudium, etc'. Num in hac vita? Minime: sed in altera, non quam vos ante iudicium ex Paracelso somniatis, sed quam Christus post vltimum diem suis electis conferet."

44 Ibid., 12: "Nunquam post lapsum Adami voluit Deus mundum ab infinitis calamitatibus liberari. Ideo enim maledicto et vanitati subiectus est, quia peccato est pollutus. Praesertim autem vltima tempora ob malitiae excessum poenis subiacent, iisque non paruis. Est enim immutabilis iustitia Dei, et lex Ge.2 et 3, promulgata." Cf. ibid., 20: "Si tempora respicimus, iam a Christo fuerunt mala, estque in vaticiniis circa finem mundi pessima fore."

45 Ibid., 5: "Post seculum in Electis tam reparationem diuinae imaginis perfectam, quam vltra cogitationes nostras sublimem gloriam fore credimus Coloss.3.v.1o. Es.64.4. 1.Cor.2.9 Non si Adam sapiens fuit in Paradiso, homines tales ante extremum diem eo modo sunt reuersuri. 
of truth: but the entire world is in wickedness." 46 Because of this, what was expressed in the manifestos could not be divine wisdom at all, and the brethren were nothing but enchanters who proposed an impossible method to acquire equally impossible wisdom. ${ }^{47}$ For Libavius, none of the Rosicrucian promises of earthly perfection were credible, because none had their origin in Scripture, and none agreed with official Lutheran doctrines. Libavius, it is clear, made sure to undermine the Rosicrucian general reformation on religious grounds.

\section{Prophecy and Paracelsus}

Libavius' criticism of the Rosicrucians' call for a general reformation also contained a critique of Paracelsianism, as Libavius suspected that the inspiration for the Rosicrucian reformation and their apocalyptic views came from Paracelsian sources. Thus also his rejection of the Paracelsian impetus of the manifestos was, at least in part, informed by religious objections. His Analysis was appended to the lengthy Consideration of the New Philosophy (1615), in which he discussed and refuted Paracelsian philosophy. ${ }^{48}$ From the opening page of the Analysis onwards, Libavius characterised the reformation plans put forward in the manifestos as "Paracelsian stupidities." ${ }^{9}$ He drew attention to Paracelsus having predicted "from the stars a revolution, a reformation, a Golden Age, and a new paradise and other things, with the blossom of his doctrine, to take place around the year $5^{8}$ (or according to others in $155^{8}$, or else 1638)"-all predictions that were also put forward in the Rosicrucian manifestos. ${ }^{50}$ If the brethren's source was not the Bible, it must be Paracelsianism,

Libenter damus sapientiam Euangelicam esse potiorem illa prima, si continuata fuerit vsque ad perfectionem: at haec non est illa vestrae reformationis." Colossians 3 refers to the time after Christ's coming when one should "put on the new man" (Colossians 3:10).

46 Libavius, Analysis Confessionis, 7: “[...] in mundo, qua est mundus, nihil nisi cadecum est. Supra: Mundus spiritum veritatis non potest accipere: sed totus est in maligno." The passage is reminiscent of 1John 5:19: "And we know that we are of God, and the whole world lieth in wickedness."

47 Libavius, Analysis Confessionis, 7: "Modum in fama ridiculum, et impossibilem proponitis, nisi putatis vos posse totum mundum incantamentis fascinare [...]."

48 Libavius, Examen philosophiae novae (1615). On Libavius about the Rosicrucian brethren as Paracelsians, see: Moran, Andreas Libavius, 239-246.

49 Libavius, Analysis Confessionis, 2, 5.

50 Ibid., 25: "[Paracelsus] ex astris reuolutionem, reformationem, aureum seculum, Paradisum nouam, et alia cum sua doctrinae flore circa annum 58. (aliquibus 1558, alias 1638) praedicere voluit, vti et 'Leonem a Septentrione' commentus est cum alliis nonnullis [...]. Videntur fratres sua ex 'Paracelso' non ex Dei voluntate hausisse. Vbi enim est Rosea crux in Euangelio? De 'spinosa Christi legimus, non de rosea' omnium bonarum abundante." According to Libavius, the predictions for the years $1658,1558,1638$ were made by Johannes 
a movement to which Libavius was already vehemently opposed. He suspected the Rosicrucians of distorting the Bible by reading it through a Paracelsian lens. When the brethren revealed their wish to correct the Church, ${ }^{51}$ Libavius believed that their correction was inspired by Paracelsus; and should they indeed "interpret the Scriptures in a Paracelsian manner," their so-called "better and more perfect science" was in fact "more corrupt."52

This was the case, for example, with the announcement of the coming of a lion. For Libavius, this was an idea as apocalyptic as it was heterodox. The figure of the lion, he insisted, had no origin in Scripture. Daniel 2 presented a dream about a statue made of four metals which were to represent four kingdoms until the end of the world, of which the first one was the kingdom of Babylon. None of them was ruled by a lion, and all would be shattered. ${ }^{53}$ Isaiah 41 furthermore spoke about a rising ruler from the north, but not about a lion. And so Libavius concluded that the Rosicrucian conception of a lion who would rule a future age did not follow from "the right principles" or from, again, the Bible, but it originated from "dreams" of "Anabaptists and stupid Paracelsians." 54 In response to the Rosicrucians' reference to the wonders of the sixth age, Libavius argued that Daniel speaks of only four kingdoms and not of six, that the kingdom of the elect will be in eternity, and that "[ $\mathrm{t}]$ he God of Daniel knew nothing about your Golden Age and about your king or lion." 55 Without a biblical basis, the

Wolf (1537-?), a religious reformer who wrote a work entitled Lectionum memorabilium et reconditarum centenarii $X V I$, which included prophetic and astrological works, including one by Paracelsus.

$51 \quad$ Fama, 98-99.

52 Libavius, Analysis Confessionis, 6: "Quo modo in doctrina et moribus fratres Ecclesiam per totum mundum dispertam poterunt corrigere? [...] Vos ne meliorem \& perfectiorem scientiam dabatis? Imo, si scripturas more Paracelsico exponetis, corruptiorem."

53 Daniel 2:31-45.

54 Libavius, Analysis Confessionis, 25: "Nos opinamur, id quod de Leone ab Oriente \& Septentrione Cabalistae \& Magi garriunt, non sumtum esse ex principiis propriis, seu ex Esaiae capite quadragesimo primo, verso vegesimo quinto: 'Suscitabo à Septentrione, \& Veniet ab ortu solis. Is praedicabit in nomine meo, \& ibit super Principes quasi super iurum, \& sicut figulus conculcat limum' [...]. Sed Anabaptistae \& stolidi Paracelsistae ad sua somnia liberaliter trahunt." Isaiah 41:25: "I have raised one up from the north, and he shall come: from the rising of the sun shall he call upon my name: and he shall come upon princes as upon morter, and as the potter treadeth clay."

55 Libavius, Analysis Confessionis, 10: "Itaque pag. 59. et 63. occupatis: 'Quod secreta nostra offerimus, id varias cogitationes excitabit' apud hos, quibus miranda sext aetatis nondum sunt nota: vel qui ob mundanum cursum, seu morem futura (in hoc tamen seculo) praesentibus paria aestimant, quique variis incommodatibus temporum suorum impediuntur, vt non aliter in mundo viuant, quam coeci [sic]. Haec est vestra prolepsis [...]. Nos inspeximus Danielis statuam, et inuenimus non sex, sed quatuor regna secularia tantum, 
Rosicrucian prophecy of a lion to rule a future period was nothing but a fiction. Evidently, because there could not be a future period, there could not be a future king, either.

Libavius thought that the origins of the lion figure could instead be found in the prophecy of "the lion from the north," ${ }^{25}$ which had been published under Paracelsus' name. He referred to the passage contained in that text concerning the treasures "protected by a certain lion, who will be the future king, and bring about a kingdom, and he will stabilise it with the treasures." Libavius remarked that this Paracelsian prophecy had also been taken up by Haslmayr. ${ }^{57}$ According to Libavius, the Rosicrucians must have had recourse to this prophecy, as he believed was evident from the very first response to the manifestos. By repudiating the apocalyptic figure that was to be responsible for its inception, Libavius also undermined, albeit indirectly, the Rosicrucians' dreamt-of political empire.

Libavius even problematised the fact that the Rosicrucian lion would "occupy and convert the treasures of the society to use against the papists," in his fight against the Antichrist. ${ }^{58}$ Noting that in some biblical passages the Antichrist was characterised by an abundance of wealth and treasures, Libavius cited Daniel 11:43, which states about the King of the North that he "will have power over the treasures of gold and silver, and over all the precious things of Egypt: and the Libyans and the Ethiopians shall be at his steps." 59 For most Protestants, this description of the Antichrist represented the pope and papacy, and the notion of a papal Antichrist is one of the very few instances where the Rosicrucians agreed with an official Lutheran position. Libavius, however, did not identify this Antichrist, or at least not solely, with the papacy. He implied that the Rosicrucian lion — which in his view was identical with the Paracelsian Lion of the North—was a representation of the biblical King of the North and thus of the Antichrist. He suspected the Paracelsians and Rosicrucians not only

quorum diebus Deus regnum Ecclesiasticum Electorum, quod erit aeternum, et non de hoc mundo, exuscitaturus sit. Deus Danielis de vestro aureo seculo et Rege, seu Leone nihil nouit."

56 Ibid., 25 , cf. above, n. 5 o.

57 Ibid., 25: "Ad thesauros quod spectat, eos aliquoties liberalissime omnibus offerunt, \& alicubi 'imperatori Romano' [...]. At iam seruantur cuidam 'Leoni, qui rex sit futurus, regnum excitaturus, idque Thesauris stabiliturus. Paracelsi' id somnium est, quod \& Haselmeierus admiratur." On Haslmayr, see above, section 4.1.

$5^{8}$ Libavius, Analysis Confessionis, 2: “[...] quo tempore Leo quidam Thesauros societatis sit occupaturus et conuersurus in usum contra Pontificios etc."

59 See: Daniel 11.43. Cf. Libavius, Analysis Confessionis, 19: "In vaticinio 'Danielis', quod ad Antichristum accommodant c.11.v.43, scriptum extat: 'dominabitur thesaurorum auri et argenti, et in omnibus preciosis Aegypti'” 
of falsely claiming to fight the Antichrist, but, more importantly still, he suspected them of being themselves the manifestation of that abominable figure that was to come at the end of time: They had boasted of having treasures originating from Egypt, which would one day be possessed by the lion:

Paracelsus also speaks of treasures of Egypt: and you [Rosicrucians] whisper about treasures. If the valuables of Egypt are ascribed to the Antichrist, watch out that you do not attract the Antichristian suspicion and opinion by that, as if your College were the Antichrist's [...]. ${ }^{60}$

Libavius possibly drew on On the Tincture of the Natural Philosophers, which was at the time attributed to Paracelsus and which described treasures that were known to the wise of Egypt. Its author claimed to possess these treasures, which could be used, he explained, for either the renovation of the body (medicine) or for the transmutation of metals and the making of gold (alchemy). ${ }^{61}$ Because the Rosicrucians had these treasures in their possession, they revealed themselves to be one with the Antichrist. By connecting this pseudoParacelsian treasure with the Prophecy of Daniel and the figure of the Antichrist, Libavius suggested that the Rosicrucians aroused the suspicion that they were in league with the Antichrist himself: "Followers of the Antichrist investigate the treasures of the world with the eyes of eagles, and pull them by claws of crows: the fraternity offers treasures for free [...]." ${ }^{62}$ Just as many Protestants believed that the pope would be punished for his luxury, so Libavius predicted that the Antichristian brethren would be "tortured in hell" for their extravagant lifestyle hinted at by their claims. ${ }^{63}$ To Libavius, their religious reformation, characterised by their fight against the Antichrist, was not merely ridiculous but dangerous.

6o Libavius, Analysis Confessionis, 19: “Paracelsus item in ore habet 'Aegypti thesauros': Et vos spiratis thesauros. Si Aegypti preciosa Antichristo addicuntur, videte ne inde suspicionem et opinionem Antichristicam trahatis, quasi vestrum Collegium sit Antichristi [...]."

61 Pseudo-Paracelsus, De tinctura physicorum, I, 14; 397: "Weiter dieweil wir nun disen schaz der Egypter in der hant haben, so wollen wir forthin sehen, wie wir uns den zu nuz machen und bringen sollen. Also fallet uns iezt aus disem spagirischen mysterio zweierlei nuz für, der eine, wie sie auf die renovation corporis möge gewendet werden, der ander, wie sie auf die transmutationem metallorum sol gebraucht werden."

62 Libavius, Analysis Confessionis, 19: "Enimuero sattellites Antichristi thesauros mundi aquilinis oculis inuestigant, et vnguibus coruinis attrahunt: Fraternitas offert thesauros gratis [...]."

63 Ibid., 13-14: "Lautitias vestras et aurei seculi somnia non possumus admittere, nisi in seculo epulari cum diuite. Luc. 16. Vultis et postea in inferno cruciari, id quod multi Canonici et Monachi, pingues ventres experientur." 
These Antichristian characteristics, Libavius noted, were at odds with the brethren's condemnation of the pope and Mohammed, and with their affirmation of the high esteem in which they held the Bible. In both instances, they had given the impression of assuring their readers that they were neither heretics nor rebels, ${ }^{64}$ thereby suggesting they adhered to the Lutheran confession, or at least a Protestant confession. Given their numerous views contradicting Lutheranism, Libavius dismissed the possibility that they could be taken for orthodox Lutherans; rather, their pronouncements seemed to represent a disguised version of the worldview espoused by the Anabaptists, members of that religious group detested by Lutherans and Calvinists alike. ${ }^{65}$ The Anabaptists had also condemned the pope, but their actions had been radical. Libavius referred to the violent Münster Rebellion of ${ }^{1534-1535}$, which was led by John of Leiden (ca. 1509-1536). During the Rebellion, Anabaptist peasants attempted to establish their community within Münster's city walls. Adherents of other confessions were forced to leave the city while their buildings were occupied or destroyed. The movement was radicalised when John of Leiden proclaimed himself King of Münster and successor of David, and he ruled the Anabaptists in Münster for a year under the pretence of divine inspiration while suppressing opposing voices. ${ }^{66}$

For Libavius, the Rosicrucian reformation and plans for change reeked of such radicalism, because "[e]ven marks of Anabaptism are in your Confession concerning that fictitious reformation, according to which, once the sinners have been destroyed, everyone will be like Adam in Paradise."67 The Rosicrucian

64 Ibid., 8: "p. 55 'non possumus suspecti esse haereseos, aut seditionis'. Cur? Quia damnamus Papam et blasphemias Mahometis. Imperatori vero Romano sponte offerimus preces nostras, arcana et magnos auri thesauros." Cf. ibid, 13: "Laudamus commendationem Bibliorum'." Libavius refers to: Confessio, 44: “[...] Orientis simul et Occidentis (Mahometen et Papam intellige) contra Jesum nostrum blasphemias detestamur [...]"; Confessio, 5758: "Illud itaque omittendum nobis minime est, ut dum aquilinae aliquot pennae nostris rebus moram tantillam ferunt, ad sacrorum Bibliorum unam, primam, assiduam, et perpetuam Lectionem adhortemur; quae si cui admodum placebunt, is multum se ad Fraternitatem nostram impetrandam profecisse sciat. Sicut ea Legum nostrarum summa: ne qua littera esset in tanto Mundi miraculo, quae memoriae non mandaretur: ita proximi ii, et maxime similes nobis, qui una Biblia suae vitae Regulam, suorum studiorum summam, Mundique universi compendium faciunt [...]." Cf. above, pp. 35-36, 5 o.

65 In his Well-intentioned Considerations, instead, Libavius considered the manifestos so elusive that he argued that it was unclear to which sect or confession they belonged: Libavius, Wohlmeinendes Bedencken, 64-66. Shackelford argues that Libavius understood Rosicrucianism as a Calvinist outburst, but evidence for this suggestion is lacking: A Philosophical Path, 337-338.

66 Stupperich, "Bockelson," in Neue deutsche Biographie, vol. 2, 344-345.

67 Libavius, Analysis Confessionis, 8: "At inquam argumentum ignorat Elenchum. Neque 
reformation was as radical as the Anabaptists' uprising in Münster, aimed at the establishment of paradise on earth. Like John of Leiden, they pretended to be divinely inspired, but for Libavius they made claims that revealed the opposite.

\section{Academic Reform and Paracelsian Magic}

Besides these apocalyptic objections to the general reformation, Libavius worried about the Rosicrucians' intentions for academies, arts, and sciences, which he believed were equally radical. As an academically taught teacher and physician, he associated himself with those institutions he believed the authors of the manifestos had wished to abolish or change, and he was determined to defend academic culture and practice against their criticism. As a rector in Coburg, for example, he upheld the teaching of grammar, rhetoric, and Aristotelian dialectic. ${ }^{68}$ Considering the Rosicrucians' call to reform the arts and the Church, ${ }^{69}$ he acknowledged that the contemporary sciences were imperfect, but how could they be otherwise when perfection was reserved for the New Jerusalem? ${ }^{70}$ The problem, for Libavius, was that the Rosicrucians wanted to establish a new truth by destroying the old one. ${ }^{71} \mathrm{He}$ rejected the alleged need for reform of the academies, and questioned the suggestion that the foundations of knowledge should disappear:

enim libet a suspicione haeresis est, qui Papam et Mohameten damnat, vt Antitrinitarii, Anabaptistae, Praedestinatiani, etc. Quin Anabaptismi vestigia sunt in confessione vestra de fictitia illa reformatione, qua deletis improbis omnes sint futuri, vt Adam in Paradiso. Ita alibi Thesauros vestros iustam causam foventi ad debellandos adversarios promittitis. Oblitine sumus belli Enthusiastici, \& Anabaptistici in Westphalia, Rege quodam Leidensi?"

68 Moran, "Medicine, Alchemy, and the Control of Language," 137.

69 Libavius, Analysis Confessionis, 6: "Societas est adeunda. Quia proponit 1. 'defectus' nostrarum artium (quae hactenus in scholis viguerunt) 2. 'remedium: 3 certa indicia' sequentium seculorum. 4. 'argumenta quibus sequentia cum praecedentibus debeant concordari. 5. Ecclesiae defectus. 6. Philosophiae moralis', (Ethice, Politicae, Oeconomicae) correctionem. 7 'res nouas', que antiquae Philosophiae (quae imperfecta, morbida, fereque iam in agone est, de quo nullum dubium est societati) minime congruunt: 8. 'noua axiomata per quae possunt saluari, vel omnia dubia explanari." Cf. Confessio, 47.

70 Libavius, Analysis Confessionis, 6: "Agnoscamus tamen defectum. Ratio est, quia multa nos latent, differendaque sunt in seculum aeternitatis [...] Hae peccato sunt obscuratae, \& instrumenta nostra secularia non possunt ferre perfectionem absolutam."

71 Ibid., 12: "Obiicis: Veritas noua non potest locum habere, nisi prius destructa (veritate) antiqua. Neque enim nouo permutari in eodem loco domicilium potest, nisi vetere ruinoso sublato." 
Who will finally preach by argument in so many churches and schools? What will be the benefit of the theological, judicial, and other interpretations erected on the fundaments of our arts and strongly opposed to heretical things and other errors? Will not every attempt undertaken and obtained hitherto in the most weighty controversies be destroyed? ${ }^{72}$

In his assessment, the alternative the Rosicrucian brethren offered remained vague, and Libavius expected it would be destructive to the hard-won consensus on difficult questions. He rejected both the Rosicrucian promise of perfect earthly studies as well as their vague proposals of reform: "If the old philosophy should be destroyed, what kind will be the new one, lest we are deceived by an empty name?"73 In his view, the brethren had no arguments as to why the old philosophy should be abolished, and he demanded: "if our philosophy and theology is bad, demonstrate this: if not, why the change?"74 The proposed reformation of both these fields must have seemed offensive to this guardian of the academic establishments. Traditional truths, he insisted, needed no perfection: in theology, the truth is contained in the Gospel, and the Rosicrucian texts provided no additional theological truths. ${ }^{75}$ As for philosophy, he acknowledged that it had been prone to error in the past, but from "the light of the divine truth" its false steps have already been revealed. ${ }^{76}$ A renovation neither of theology nor of philosophy was necessary.

What was worrisome to our academic spokesman was the Rosicrucian alternative to established arts and sciences, which was, Libavius believed, Paracelsian magic. Having already dismissed, in the Consideration of the New Philosophy, the new philosophy of Paracelsus and his followers, with its Hermetic and occult tendencies, Libavius criticised the "Rosicrucian sect" for similar reasons. He concluded that one did not need "magical Paracelsians and those

72 Ibid., 6: "Deinde quis persuadebit tot Ecclesiis et scholis? Quid proderunt interpretamenta Theologica, Iuridica, et alia ex fundamentis artium nostrarum extructa, et haereticis, aliisque erroribus fortiter opposita? An non omnis conatus hactenus in controuersiis grauissimis adhibitus, et obtentus pessumibit?"

73 Ibid., 6: "Si vetus philosophia deleri debet, qualis erit noua, ne nomine circumducamur nudo?"

74 Ibid., 13: "Ita vos fratres, si Philosophia et Theologia nostra mala est, demonstrate hoc: Si non, quorsum mutatio?”

75 Ibid., 13: "Quod ergo argumentum attinet, societas non est adeunda arcis nouae veritatis caussa, quia antiquius verius. Si veritatem iam habemus, ad noua declinare fas non est [...]. Est ergo iam arx veritatis Canonicae Scripturarum authenticarum septis circundata: nec est nisi 'vnum de vno' verum [...]. In Theologicis igitur veritas a vobis nulla potest extrui.” Ibid., 13; cf. below, n. 77. See also: Libavius, Exercitatio Paracelsica nova, 289-29o. 
phantasiasts, who draw up stories about the living or vital philosophy."77 As we have seen in Chapter Two, Paracelsus believed that the world consisted of, and was animated by, life forces, an immaterial reality immanent in the material visibility. In the works of several later Paracelsians, such as Petrus Severinus, this idea mingled with corpuscularism, namely with the worldview constituted when the original notion of atoms became incorporated into the concept of the living semina. This notion supported the understanding of an inner vitality in nature, which was represented in a vital philosophy. ${ }^{78}$ Libavius also identified atoms as living semina, ${ }^{79}$ but when attacking the Rosicrucians he believed them to have endorsed Paracelsian fables about the vital philosophy, which he claimed offended God and were contaminated by magic. Libavius had already attacked the Paracelsian interpretation of the vital philosophy in his Consideration, when refuting the philosophy of the Paracelsians Severinus and Hartmann. ${ }^{80}$ He now related the proclaimed Rosicrucian reformation of the arts and sciences to Paracelsian novelties, and wished to shield university education from such fanatical ideas:

We already smell the breath of detestable magic: because from which other source would either your supplement or correction [to the sciences] flow than from the magic, Cabala, and similar absurdities of Paracelsus? So the remedy is suspect. ${ }^{81}$

According to the Fama, Christian Rosencreutz had been taught Cabala in Fez, where he had learned about the secrets of nature. When the authors of the manifestos claimed to study the secrets of the world, Libavius explained, they in fact professed "the science of these secrets through magic, Cabala, and

77 Libavius, Analysis Confessionis, 13: "Philosophia fuit erronea. At haec lumine veritatis diuinae, et experientia iam ita est illustrata, vt qui aliam vobis velit obtrudere, eum pro falsario habeamus, sicut magos Paracelsicos, et Phantastas illos, qui de viuente, seu vitali Philosophia fabulas conscribunt." On Libavius' criticism of Paracelsus and Paracelsians, see, for example: Moran, Andreas Libavius.

78 Shackelford, "Transplantation and Corpuscular Identity in Paracelsian Vital Philosophy." On semina, see: Hirai, Le concept du semence; Moreau, "Eléments, atomes, et physiologie," 123-178.

79 Newman, Atoms and Alchemy, ch. 3.

8 o Libavius, Examen philosophiae novae, $88 \mathrm{ff}$.

81 Idem, Analysis Confessionis, 6: "Societas est adeunda. Quia proponit 1. defectus nostrarum artium (quae hactenus in scholis viguerunt). 2. remedium. [...] nos iam olfacimus Magiae detestandae halitum: Nam ex quo alio fonte scaturiet vestrum seu supplementum, seu correctio, quam ex Magia, Cabala, et similibus Paracelsi ineptiis? Itaque remedium est suspectum." 
similar Paracelsian arts," which cannot make anything "without the help of spirits and without imposters." 82

In this context, Libavius was particularly taken aback by Haslmayr's Answer, published together with the Fama and Confessio, wherein he "has ordered you to come, and to change the entire philosophy and to repair the defects of theology, and to shape the state after the form of the magi in Damcar"83 — that is, to reform the three realms of religion, politics, and knowledge. Haslmayr had associated the Rosicrucians with Paracelsian thought, but he had not referred to Damcar. But since Rosencreutz had wanted to establish his society in imitation of those he had encountered during his sojourns in the Arab world, Libavius linked the Rosicrucians' magic to their presumed Muslim sympathies. They may have condemned Mohammed, he observed, but in fact their magic was heretical and dangerous not only for its Anabaptist and Paracelsian characteristics, but also for what he believed were Islamic features: "Oh those happy and fortunate, who have not entered into the society of the Rose Cross, because it is entirely magical and impure, and it smells of peculiar Anabaptist folks because of Paracelsus, the impious Arabs, and the cursed [Islamic] Mauritanians." 84

According to Libavius, the Rosicrucian brethren had suggested that their wisdom came from God, but in his view the magic they professed was the same as that of the Arabs and Paracelsians, and was diabolical. ${ }^{85}$ For magic, he explained, could only come about through communication with the devil, as was confirmed by Paracelsians and "magicians" from the past. ${ }^{86}$ Whereas

82 Ibid., 8: "Ab omni enim aeuo compertum est, nihil vanius esse magia, et qui profitentur scientiam arcanorum istorum per Magiam, Cabalam, et similes artes Paracelsicas, Techelicas, Artefianas, etc. eos 'sine spirituum auxilio et imposturis' nihil potuisse."

83 Ibid., 22: "[...] Haselmejerus iussit vos venire, vosque ipse totam Philosophiam immutare Theologiae defectus sarcire, vt Politias ad 'Magorum in Damear' [sic] formam componere desideratis."

84 Ibid., 22: "O felices et beatos eos, qui non ingreßi sunt societatem de Cruce Rosea, quia tota est magica, et impura, sapitque Anabaptisticum singulare genus ex Paracelso, Arabibus impiis, et Mauritanis execratis." Elsewhere Libavius claimed that Christian Rosencreutz had travelled to Mauritania: Libavius, Wohlmeinendes Bedencken, $5^{\circ}$.

85 Libavius, Analysis Confessionis, 8: "Probare debet societas, Deum reuera offerte ista secreta [...]. Suspitio itaque est, nomen Dei tantum esse praetextum professioni magicae ex Arabia et Mauritania, vel Paracelso haustae."

86 Ibid., 8: "Nimirum hic est ille praetextus Diabolicus, quo Paracelsus, Crollius, Tritemius, Scotus, Agrippa, Simoniani, Basilidiani, Menandirini, etc. haeretici: Zoroaster, Osthanes, Tiridates, Apollonius, Tyanaeus, Zyto Bohemus, Actius, Nauius, Numa, et similes execrabiles magi suam abominabilem artem palliant, licet explodendi, ridendique omnes, cum nihil mirabilium sine Diabolorum commercio vnquam praestiterint, et inanibus ver- 
academies were illuminated by the divine truth, Paracelsians and Rosicrucians were magicians who had been seduced by Satan and who wanted to contaminate universities. Their supposed remedy to the sciences could not be trusted, unless they use Scripture rather than untrustworthy documents "from the extasies of enthusiasts, or from the stupid prophecies of Paracelsus, fanatic astrology, overcome by visions, etc." 87 Without the evidence of a foundation in Scripture, Libavius dismissed the Rosicrucian reformation of philosophy and scientia.

The reformation announced in the manifestos included also the reform of medicine, so that Libavius made sure to attack the proposed reform of this art as well, which he believed to be equally magical. As an alchemist, he recognised the use of alchemy in Paracelsian recipes, and his criticism of Paracelsus and Paracelsianism was never directed against alchemical medicine or spagyria as such. In that sense, he moved between the Hippocratic-Galenic tradition and the new Paracelsian medicine. ${ }^{88}$ What he considered problematic and diabolical was the use of "superstitious" alchemy: the Paracelsians' art of making the philosophers' stone and a universal medicine. ${ }^{89}$ Some Paracelsians, he wrote, searched for the "philosophical stone" and for the universal medicine, while others took their medicine from chiromancy (palm reading). ${ }^{90}$ These were the types of alchemy that were propagated in pseudo-Paracelsian writings like the Apocalypse of Hermes, On the Tincture of the Natural Philosophers,

borum ampullis linant chartas, quibus Sathanas seducit Paracelsistas praestigiosa vaniloquentia circumductos."

87 Ibid., 11: "Quod autem Dei defensionem et voluntatem praetenditis, temere est. Non enim inuenitis fidem, nisi documenta fidelia offeratis, non ex raptibus Enthusiasticis, Paracelsi fatuis Prophetiis, astrologia fanatica, visionibus victis, etc., sed Verbo Dei, quod plane contrarium habetis."

88 In his Pro defensione syntagmatis chymici contra reprehensiones Henningi Scheunemanni, Libavius wrote, for example: "I also count Paracelsian recipes among the ones in my Alchemia, for I am not so hostile to Paracelsus as to say that there is nothing good in his writings. But I do not thereby want to be called a Paracelsian. Do you ask why? Because that word signifies a certain disposition and the entire profession of a certain faction," cited in: Moran, Andreas Libavius, 151.

89 On Libavius' battle against these types of alchemy, and his ambiguous stance towards the art of making gold, see: Moran, Andreas Libavius, 31-33, 70-71, 178, 248n67.

90 Libavius, Analysis Confessionis, 8: "Per totas descriptionem istarum artim Diabolicarum, licet Paracelsici eas pro naturalibus et diuinis proponant. Quidam lapidem Philosophicum et vniuersalem medicinam quaesiuerunt, et adhuc quaerunt: alii in mistis inuestigant essentias, et medicinas eliciunt ope cuiusdam chiromantie, quae signaturas rerum doceat, et anatomias." 
and the Manual, while chiromancy was described in the spurious On the Nature of Things. ${ }^{11}$

Libavius may have had such pseudo-Paracelsian tracts in mind when rebutting the manifestos. Like the authors of these writings, the brethren claimed to have the universal medicine in their possession. With such a cure, Libavius remarked, they could abolish Galenic medicine, in fact all medicine, and make use of this "single axiom" only. ${ }^{92} \mathrm{He}$ mockingly suggested that all those people suffering from poverty and diseases or desiring to acquire long life could find respite in the fraternity:93 "Whoever does not want to fear hunger, poverty, diseases and old age, bring yourself to the society of the Rose Cross." ${ }^{94}$ The Rosicrucian reform of medicine was deceptive: universal medicines were not to be trusted, and Paracelsians and Rosicrucians alike merely deceived their readers with foolish promises; so Libavius further vented his disdain: "But you have the renovating panacea and many magical antidotes. So you will pass away not as old men, but as youngsters of many years, [just] like your Paracelsus and other Paracelsians [...]."95 For Libavius, the irony lay in the well-known fact that Paracelsus had not reached old age, but had died prematurely, presumably as a result of quicksilver poisoning. ${ }^{96} \mathrm{He}$ jokingly suggested that the Rosicrucian brethren wished to follow Paracelsus' example: their universal medicine was in fact a means to a premature death, and so indeed they would not suffer from old age. It was evident to Libavius that Paracelsians had falsely ascribed magical powers to Paracelsus, and the Rosicrucian promises were equally

91 Pseudo-Paracelsus, De natura rerum, I, 1;320 ff. Cf. Chapter 2. Two relevant authentic works by Paracelsus include: Paracelsus, Zwei frühe Ausarbeitungen über das Podagra, I, 11; $384 \mathrm{ff.;}$ idem, Astronomia Magna, I, 12; 4-444.

92 Libavius, Analysis Confessionis, 13: "Arg IIX. 'si in vna veritate est acquiescendum eaque compendiose inuenitur apud societatem haec est adeunda illud est. Et hoc ergo'. Ratio connexionis est: Si enim non est adeunda societas pro veritate compendio discenda, per multas ambages erit ad eam tendendum. Nam alias per longos circuitus, et perplexitates quaeri solet [...]. Responderi potest, non probari id quod probandum erat, nempe veritatem illam vnam sine ambagibus apud societatem inueniri, et alibi non tam explanare, et summatim disci posse. Vestro dicere non sumus contenti [...]. et vos si 'Panaceam', qua gloriamini, habetis, potestis totam Medicinam abrogare, et vnico axiomate omnem vim eius complecti."

93 Ibid., 13-15, arguments IX-XII.

94 Ibid., 13: "Qui non vult famem, egestatem, morbus, \& senectutem timere, conferat se ad societatem de Rosea Cruce."

95 Ibid., 14: "Sed vos Panaceam renouatoriam et magica plurima alexicaca habetis. Itaque non senes, sed iuuenes multorum annorum deceditis, vt Paracelsus vester et alii Paracelsistae $[\ldots] . "$

96 On Paracelsus' death, see: Harrer, "Zur Todeskrankheit des Paracelsus." 
unbelievable. ${ }^{97}$ Paracelsians and Rosicrucians pretended to practise science, be physicians, and have wisdom, but instead their science was magic and they themselves were unable to restore health to diseased bodies.

It comes as little surprise that Libavius dismissed the panacea also on religious grounds. Another reason for Libavius' problem with the promised panacea and its alleged promise of eternal and healthy lives could be found in the Holy Scriptures. On the matter of eternal youth, the Bible taught that even the old Patriarchs were mortal. Abraham and Sara, Libavius explained, were old and affected by their age, just like Isaac (Genesis 18:11-12; Genesis 27:1). ${ }^{98}$ Given that the Rosicrucians could never possess a magic that made them less mortal than the Patriarchs, "[i]t follows from this that you cannot be immune from diseases and old age, irrespective of whether you have the stone, or tinctures, or seals and other constellations." ${ }^{\prime 99}$ After all, restoring bodies to original perfection and paradisiacal conditions, free from diseases and the poison of death, would imply that perfection was possible before the end of the world, thanks to magical means and without divine intervention-a conception Libavius, like all mainstream Lutherans, condemned.

In sum, for Libavius, the Rosicrucians' general reformation could be refuted in many ways, and for three reasons in particular: its millenarian imagery, its attempt to alter academic education, and its Paracelsian inspiration. The latter objection is unsurprising, given Libavius' many attacks on Paracelsus and his followers; but his dismissal of the Rosicrucian reformation on confessional grounds is salient. His views were akin to those of orthodox Lutherans, even though his response was written at a time, the 1610s, when several Lutherans had already come to accept a so-called "millenarian" worldview. ${ }^{100}$

Libavius presented himself not just as a spokesman for institutional learning and an opponent of Paracelsianism, for which he is well known, but also as the mouthpiece of orthodox Lutheranism, horrified as he was by apocalyptic

97 Libavius, Analysis Confessionis, 13: "Paracelsus sine morbo non decessit, qui tamen in manuali, \& alibi grandia à se praestita per tincturam scribit. Magicis sigillis, Gamaheis, characteribus, \& similibus crepundiis eam vim asscribunt Paracelsici, sed falso. Si viueretis in insulis fortunatis, vbi nulla est corruptio, crederem."

98 Ibid., 14.

99 Ibid., 14: "Sequitur ex his, vos non posse immunitatem a morbis, et senectute habere, siue lapides habeatis siue tincturas, siue sigilla et alia constellata." In margins: "Quidam lapidem habuerunt, sed nullos nec suos nec aliorum morbos sustulerunt, nedum diu vi lapidis vixerint." Libavius refers to Genesis 47:9, Psalms 90:7, Genesis 18:11-12, Genesis 27:1, Deuteronomy 30:20.

100 On this, see especially: Penman, "Repulsive Blasphemies"; idem, "Climbing Jacob’s Ladder”; idem, "Between Utopia and New Jerusalem”; idem, Hope and Heresy. 
promises of future earthly perfection and further reform. These three aspectsthe so-called millenarian views, the call for reform, and the Paracelsian inspiration-served as grand themes under which Libavius discussed or touched upon many elements related to the Rosicrucian call for a general reformation: the reform of religion, politics, and knowledge, the Antichrist, the lion of the North, the hopeful messengers in Serpentarius and Cygnus, the notion of perfect wisdom before the end of the world, the optimistic conception of time, and the reform of medicine. Each of these elements he discussed, ridiculed, and sought to discredit. In this context, he dismissively referred to Haslmayr twice, whose Answer had by this time spread widely, but who had promoted almost none of these themes. Haslmayr had not argued in favour of a new earthly period or another earthly reformation, but his was the only name that was publicly associated with the Fama and Confessio. Haslmayr was also a proclaimed Paracelsian, a Catholic, and held apocalyptic views - which must have been reasons enough for Libavius to reject him.

\section{Fludd: Academic Reform and Magical Aspirations}

The year after the publication of Libavius' Analysis, Robert Fludd felt compelled to defend the brotherhood against what he considered unwarranted criticism. Fludd had matriculated in medicine at Oxford and entered the College of Physicians in London in the early 1600 s, after many failed attempts resulting from his hesitant acceptance of Galenism. ${ }^{101} \mathrm{He}$ was a friend of the physician William Harvey (1578-1657), whose theories on the circulation of blood he supported, ${ }^{102}$ and he was involved in a famous dispute with Kepler, which included various cosmological matters. ${ }^{103} \mathrm{He}$ was also alleged to have been a friend of Michael Maier, but this suggestion has recently been challenged. ${ }^{104}$ Although Fludd, through his profession, was acquainted with academics, his writings were far from scholarly. He was a Hermetic philosopher and is known for his Hermetic and medical ideas, astrological aspirations, and magical theories. This

\footnotetext{
101 Fludd, Apologia Compendiaria, 22; Debus, "Fludd, Robert," in Dictionary of Scientific Biography, vol. v, 47.

102 Huffman, Robert Fludd, 20.

103 On Fludd's controversy with Kepler, see: Yates, Giordano Bruno, ch. 22; Anman, "The Musical Theory and Philosophy of Robert Fludd"; Schmidt-Biggemann, "Robert Fludds Streit mit Johannes Kepler"; Lüthy, "What Does a Diagram Prove that Other Images do Not? Images and Imagination in the Kepler-Fludd Controversy." On Fludd's controversy with Mersenne and Gassendi, see for example: Schick, Das ältere Rozenkreuzertum, 265270; Hutin, Robert Fludd, 52.

104 For literature suggesting that Fludd and Maier were friends, and for literature casting doubt on this thesis, see: Tilton, Quest for the Phoenix, 27nıog.
} 


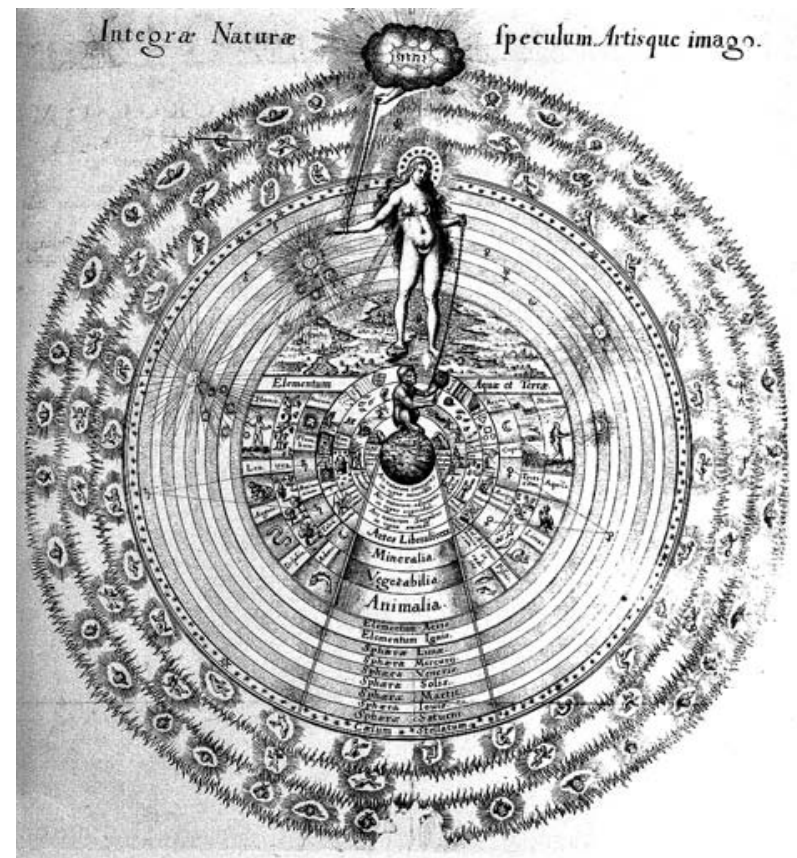

FIGURE 13 Robert Fludd, Utriusque cosmi historia, Wellcome Collection

worldview was given its fullest expression in The Metaphysical, Physical, and Technical History of the Two Worlds, Namely the Greater and the Lesser (16171621). ${ }^{105}$

Fludd's reputation was largely due to his work as a defender of the Rosicrucians. His first defence of the Rosicrucians appeared in A Short Apology (1616), in which he explicitly referenced and refuted Libavius' attack. In this text, he explained his desire to become a Rosicrucian, a role for which he thought himself well suited, being a nobleman and physician. ${ }^{106} \mathrm{He}$, like many other Rosicrucian enthusiasts, read the manifestos as messengers of hope. Each of those aspects that Libavius most refuted, Fludd promoted emphatically. He relished in the promises of improvement and thought to perceive evidence enough for the need of it. And whereas Libavius set down his objections struc-

\footnotetext{
105 Fludd, Utriusque cosmi, maioris scilicet et minoris, metaphysica, physica, atque technica historia (1617-1621).

106 Idem, Apologia Compendiaria, 22: "Quis ego, paucis accipite, qui nempe comitibus vestri ordinis ultimum me libentissime facerem, quo aures humanas bibulas digniori et certiori vestrae laudis susurrro [sic] permulcerem, nomine ut supra seu Flud, natu satis nobilis, sed minimus: gradu Med.D. sede Londinensis."
} 
turally by means of an array of careful arguments, Fludd seized the opportunity to refute them all at once. The Fama, he wrote, had "passed through almost all provinces of Europe and reached our ears at last." "Thus," he asked, "why is the monastery of their order not sought out diligently," and "why are [the manifestos] to be rejected so easily?"107 He was quick to dismiss the attempt of Libavius to critically examine the fraternity and its mission statements. For Fludd, Libavius' Analysis represented nothing but the "bitterness and envy of a pen." ${ }^{108}$ So he took upon himself the tasks of investigating the fraternity and of defending it against the "groundless accusations of D. Libavius and others,"109 to cleanse the society from the dirt that had been thrown at it, and to reveal the society's true splendour. Fludd's project was twofold: on the one hand, he needed to refute Libavius' criticism; on the other hand, he aimed to communicate the true intentions and merits of the society.

When Fludd responded to Libavius, he was not doing so as an academic physician. As a physician, he used Paracelsian recipes and cures, but his basic objection to Libavius concerned apocalypticism. Like Libavius, he had recourse to the Bible, and he used biblical passages - sometimes the same passages as Libavius had-but, conversely, to the advantage of the Rosicrucians. He was well aware of Libavius' reference to 1Thessalonians 5, which suggested that one should test all prophecies and maintain the good ones. ${ }^{110}$ Fludd also used that passage to explain the need to investigate the Rosicrucian manifestos. But he did not start by discussing the Rosicrucian general reformation, which had informed the main thrust of Libavius' attack. Instead, he aimed to show the divine origin and nature of the manifestos, and in doing so he touched upon the Rosicrucians' reform plans and the elements related to it.

When contesting Libavius' criticism, Fludd set out to logically demonstrate the origin of the Rosicrucians' revelations: were they indeed, as Libavius had

107 Ibid., 6-7: "Fama Societatis de Rosea Cruce omnes fere Europae provincias peragravit et tandem ad aures pervenit nostras, admirabilem ipsius scientiam in arcanis tam divinis quam naturalibus e buccinando. Cur igitur non est huius ordinis coenobium diligenter inquirendum, et inquisitione inventum tandem adeundum cum liberaliter, sua sponte, nulla adhibita vi et gratuito se nobis oblaturum scriptis et sermonibus divulgatum sit. Aut cur ita leviter reijcienda sunt [...]?"

108 Ibid., 7: "Cui certe dubio respondere videtur D. Libavius in sua Analysi confessionis fraternitatis de Rosea Cruce: in qua plus amaritudinis et calami malevolentiae (scripta eius diligenti intuitu perpendendo) deprehendemus quam radicalis rei inquisitionis."

109 Ibid., 7: "Hinc igitur est quod in fraternitatis causam descendam, eamque tam telis ipsius proprijs quam ex pharetra aliena depromtis contra calumniosas hasce D. Libavij et aliorum aspersiones defendere animo proposuerim." It is unclear who Fludd had in mind here as other attackers on the Rosicrucians.

110 Ibid., 6. Cf. Libavius, Analysis Confessionis, 3. 1 Thessalonians 5:20-22: "Despise not prophesyings. Prove all things; hold fast that which is good. Abstain from the appearance of evil." 
argued, the result of communication with the devil, or did they have divine origins? The first step in challenging Libavius' accusations was to thoroughly investigate the matter at hand:

Let us therefore investigate and examine with concern the actions of these brethren and consider their practices and conditions with a sharp and earnest mind, and having reflected upon all things carefully, let us detect with the right mind and before the eyes of the intellect, and let us investigate whether the brethren here are from God or from the devil. ${ }^{111}$

Fludd examined the ways and extent to which the Rosicrucians were divinely inspired. He began by explaining how God, and more specifically the Holy Spirit, "is known from [His] gifts."112 Already in the Bible, the Holy Spirit was characterised as the harbinger of gifts. According to 1 Corinthians 12:7, the gifts of the Holy Spirit should be used to the advantage of the common good. ${ }^{113}$ Appealing to these examples, Fludd explained how Moses and Aaron had received the Holy Spirit to "educate the people of God."114 He presumably drew on 1 Corinthians 12 when he listed the many gifts that could be seen as signs and testimonies of the presence of the Holy Spirit: ${ }^{115}$

Therefore those who speak the truth, prophesy, see true visions, dream dreams, speak in new language, interpret Scripture, cast out demons, fully help and heal the sick, observe the divine teaching, do not resist the word

111 Fludd, Apologia Compendiaria, 12-13: "Inquiramus igitur et cum solicitudine perpendamus fratrum horum actiones, eorumque mores et conditiones acri et intento animo intueamur, omnibusque sedulo ponderatis, mente iusta comprehendamus et ante oculos intellectus, An fratres hi sint a Deo, aut a Diabolo, proponamus."

112 Ibid., 13: "Invenimus, quod spiritus sanctus ex donis congnoscatur."

113 1Corinthians 12:7: "But the manifestation of the Spirit is given to every man to profit withal" (KJV); "Now to each one the manifestation of the Spirit is given for the common good" (NIV).

114 Fludd, Apologia Compendiaria, 13: "Legitur quod in unoquoque elucescant dona spiritus sancti ad communem utilitatem. 1 Corint. 12. Sic Moyses, Aron, et alij Patriarchae et Prophetae spiritum sanctum, non sui ipsius causa acceperunt, sed ut populum Dei docerent $[\ldots]$."

115 Ibid., 13-14: "Sed ulterius adhuc inquirendum profendiusque speculandum, an cum caeteris spiritus donis conveniant operationes et gesta eorum et primum quae sunt signa et testimonia ex quibus spiritus sancti praesentia in hominibus arguitur, propenso animo ruminemus: deinde vestigia eorum in confessione sua premamus et consequamur, penitusque introspiciamus quot testimorum [sic, supra: "testimoniorum"] praedictorum impressiones in ea investigantur." 
of God, work from the fruit of the Spirit, such as love, joy, peace, charity, generosity, humanity, goodness, mildness, moderation, purity: and do not pursue the works of the flesh, such as fornication, impurity, shamelessness, idolatry, sorcery, enmity, murder, greediness, wrath, discord, and other such things - those are without doubt filled by God and His sacred Spirit, since these are those infallible indications about which we were instructed from the Holy Scriptures to recognise humans illuminated by the Holy Spirit, and to distinguish them from those of another kind. ${ }^{116}$

Having established which are the gifts of the Holy Spirit, the next logical step for Fludd was to "examine whether these gifts can be found in the fraternity or not." ${ }^{117}$ Such a search, he believed, was easily carried out, because in similarity to Moses and Aaron the brethren wrote their prophecies to the advantage of all: "It is thus an important sign of the fruit of the Holy Spirit in the brethren that they also have set out in public their prophecies and sciences for the common good."118 Further testimonies of the Holy Spirit's presence within the fraternity included their speaking of the truth, their sincere lifestyle, and their observation of the divine teachings not from their own judgement but "from the Holy Spirit and the advice of God."119 For Fludd, the brethren were demonstrably pious men, living apostolic lives and having received divine illumination. They were not inspired by the devil but by the Holy Spirit.

Fludd argued that such immediate illumination was possible for everyone, and was in fact consistent with certain passages in Scripture. He referred to

116 Ibid., 14: "Quicunque ergo veritatem loquuntur, vaticinantur, veras visiones vident somnia somniant, novis linguis loquuntur, Scripturam interpretantur, daemonia eijciunt, aegros perfecte curant et sanant, praecepta divina observant, verbo Dei non resistunt, fructus spiritus operantur, ut sunt Dilectio, Gaudium, Pax, Charitas, Liberalitas, Humanitas, Bonitas, Mansuetudo, Temperantia, Castitas: \& opera carnis non exequuntur, qualia sunt Scortatio, Impuritas, Impudentia, Idololatria, Veneficium, Inimicitia, Homicidium, Gula, Ira, Discordia, et id genus alia, hi procul dubio a Deo sunt et spiritu ejus sacrosancto pleni, quoniam haec sunt indicia illa infallibilia quibus a sacris scripturis docemur homines spiritu sancto illuminatos cognoscere et ab illis alterius farinae distinguere." See 1 Corinthians 12.

117 Fludd, Apologia Compendiaria, 13: "Examinemus igitur, an haec dona in fraternitate reperiantur, necne."

118 Ibid., 13: "Est igitur indicium fruitionis spiritus sancti in fratribus non exiguum quod in publicum etiam suas prophetias et scientias ad commune beneficium proposuerunt."

119 Ibid., 15: "Videamus nunc fratrum confessionem, ex qua tandem diligenti examine de gradu in gradum facto, colligimus quod [...] veritatem loquantur [...], quoniam vitam syncere agunt: praecepta divina observent, quae scribunt se non impulsu sui arbitrij, sed spiritu sancto et Dei monitis hoc fecisse." 
Joel 2:28: "And it shall come to pass afterward, that I will pour out my spirit upon all flesh; and your sons and your daughters shall prophesy, your old men shall dream dreams, your young men shall see visions." For Fludd, divine inspiration did not need to be mediated by Scripture, and so he encouraged his readers to follow the example of the Rosicrucians and strive for spiritual gifts. ${ }^{120}$

Fludd subsequently addressed the accusation, made by Libavius, that the fraternity was using devilish magic, and that its brethren were suspect of sedition and diabolical delusions. ${ }^{121}$ Such accusations did not sit well with the Hermetic philosopher, Fludd, who invariably propagated the use of magic. He argued that Libavius tried to besmear the brethren with the charge of heresy without having properly examined the matter at hand. ${ }^{122}$ According to Fludd, the Rosicrucians were indeed occupied with magic, but this was laudable. In the manifestos magic was not explicitly addressed; much less could it be seen as a central element of their general reformation. They did speak of the microcosm-macrocosm analogy, the Book of Nature, and their own possession of the Adamic tongue to express divine secrets-but these philosophical elements were not specified as being magical. For Fludd, however, they provided sufficient evidence of their magical knowledge.

Fludd explained that there were two types of magic: the first originated from the Holy Spirit, and was a natural type of magic; the other came about through association with the devil and was called diabolical magic. This difference relates to the Renaissance distinction between natural magic and diabolical magic, the latter sometimes called ceremonial magic. Natural magic was considered acceptable and was related to natural philosophy, but diabolical magic was to be rejected. Natural magic was believed to come about by natural

120 Ibid., 11-12: "Exhortamur etiam amorem sequi et dona spiritualia appetere ut inde vaticinemur. 1 Corinth. 14. Non, inquam, spernendae fratrum propositiones, cum sit possibile quod vera spiritus sancti eluminatio et plena cognitionis satietas a Deo etiam in singulos hujus seculi homines concinne distribuatur, secundum illud prophetae Ioël 2. Deus per os Prophetarum suorum promisit, quod velit de suo spiritu effundere super omnem carnem, et filij et filiae hominum prophetabunt, et juvenes visiones videbunt, et senes somnia habebunt. Similiter pollicitus est se illis omnibus, qui eo nomine ipsum invocaturi sunt, daturum Spiritum S. qui sit ipsos edocturus omnem veritatem. Luc. 12 Joh. 14. 15. Et alibi, Docebuntur omnes a Deo."

121 Ibid., 7: "Nam uno loco fratres in seditionis suspicionem [Libavius] adduxit. Alibi eorum promissa perfici et patrari non posse contendit sine Magia detestanda aut praestigiis Diabolicis."

122 Ibid., 7: "Deinde haeresi ipsos commaculare studet, veritatem fortassis mendacio contaminando, cum pro extrema iniustitita haberi soleat in re aliqua accusare alterum eumve criminis aut sceleris condemnare, tanquam effectibus, priusquam causa accurate exploretur et debito modo examinetur." 
forces, while diabolical magic was performed by means of powers from the devil. ${ }^{123}$ Fludd reproached Libavius for having failed to distinguish between these two types of magic; Libavius had regarded all magic, especially that of the Paracelsians and Rosicrucians, as diabolical. ${ }^{124}$ But, according to Fludd, with their Confessio the brethren had "removed any imagination of deception," and "therefore the suspicion of any diabolical art is to be removed from them by far, and to be despatched by humans to the furthest reaches of oblivion." ${ }^{125}$ Instead of being practitioners of devilish magic, he claimed, the members of the fraternity practiced magic that was inspired by the Holy Spirit. Possibly still under the inspiration of 1 Corinthians 12 , Fludd claimed that they were dedicated to the "true philosophy," and performed their magic "by the admonition of the Holy Spirit, who is wont to teach everything not by deception, but by the very pure truth itself." 126 In his response to Libavius, Fludd concluded that the Rosicrucians' philosophy, as the alternative to established learning, was sound, and that their reformation was justified.

Fludd's discussion of magic had its origins in his own worldview, which is expressed in his book on the two worlds. ${ }^{127} \mathrm{He}$ associated the Rosicrucians with Hermeticism and Renaissance magic, the traditions with which he himself had a close affinity. ${ }^{128}$ By arguing that the brethren had received their gifts and magic from the Holy Spirit, from which they taught about divine secrets, ${ }^{129}$

123 The distinction is complex and differed per philosopher. Ficino, Pico, Pomponazzi, and Agrippa, for example, distinguished natural magic from diabolic or black magic. On this difference, see, for example: Thorndike, History of Magic and Experimental Science, 8 vols.; Copenhaver, "Natural Philosophy: Astrology and Magic"; idem, Magic in Western Culture, 272-33o; Zambelli, White Magic, Black Magic in the European Renaissance.

124 On this, see: Moran, Andreas Libavius, 244.

125 Fludd, Apologia Compendiaria, 8-9: "Quae quidem confessione (ni fallor) se de hoc crimine purgaverunt, omnemque seditionis imaginationem sustulerunt. Alibi etiam in confessione invenimus, quod Christum pure et syncere amplectantur, vitamque Christianam agant: unde omnis artis Diabolicae suspitio ab ijs procul est amovenda, inque ultimas oblivionis oras ab hominibus releganda." Cf. ibid., 9: "Nam qui Christum vere et syncere venerantur, majora virtute ejus sacrosancta complere et ad exitum faeliciter perducere possunt, quam praestigiosis et vanis Diaboli illusionibus, a quibus fratres hos liberos omnino esse colligimus."

126 Ibid., 9: "[...] quoniam in uno suae confessionis loco se verae philosophiae addictos esse narrant [...] et in alio, hanc ipsorum motionem non processisse impulsu sui liberi arbitrij, sed admonitione Spiritus sancti, cuius est, omnia non fallacijs, sed pura et ipsissima veritate docere."

127 Fludd, Utriusque cosmi, maioris scilicet et minoris, metaphysica, physica, atque technica historia.

128 Cf. Copenhaver, Magic in Western Culture.

129 Cf. Fludd, Apologia Compendiaria, 14. 
Fludd implied that their philosophy was pious. Not unlike Maier, but opposing Libavius, he made it clear that their reformation and contribution consisted in bringing back an ancient pious philosophy. He explained that ancient philosophers had taught us that "Moses the high priest of divine philosophy has reached the border of happiness,"130 and that biblical prophets and ancient philosophers like Hermes Trismegistus had possessed an equally divine philosophy:

Bezalel, Joshua, David, Solomon, and all prophets approached his [Moses'] virtue: several of the old philosophers imitated their wisdom, among whom Mercurius Trismegistus is seen to claim the first place for himself, whose sacred sermons give us a lively picture of his wonderful knowledge of what is above and below, and of his science in the Emerald Tablet. ${ }^{131}$

Fludd associated Mosaic, pious philosophy with the Hermetic tradition, and suggested that it was now revealed once more in the Rosicrucian manifestos. Fludd consistently tried to base his own philosophy on the Mosaic books. ${ }^{132} \mathrm{He}$ explained that Moses, the father of divine philosophy, "when he had a conversation with God, he obtained the key of both studies (namely supernatural and natural) by the divine help of the Holy Spirit and by illumination."133 Moses could engage in dialogue with God without mediation, thanks to which he could learn about the divine and the natural worlds. Because the brethren were also inspired by the Holy Spirit, such abilities were now present in the Rosicrucian fraternity, and its members possessed the key to understanding the secrets of the worlds above and below, in keeping with the Emerald Tablet.

130 See n. 133 below.

131 Fludd, Apologia Compendiaria, 4-5: "Huius [Moses's] virtuti accesserunt Bezaleel, Iosua, David, Salomon \& omnes prophetae: quorum etiam sapientiam imitati sunt nonnulli philosophorum veterum, inter quos primum videtur Mercurius Trismegistus locum sibi assumere atque vendicare, cuius mirabilem superiorum \& inferiorum cognitionem vivaciter nobis depinxerunt Sermones eius sacri, eiusque in tabulis Smaragdinis scientia."

132 Debus, "Fludd, Robert," in Dictionary of Scientific Biography, vol. v, 47.

133 Fludd, Apologia Compendiaria, 3-4: "Quod tamen sit certa quaedam \& indubitata faelicitatis humanae sedes in hoc mundo, \& à nonnullis longa peregrinatione \& debita inquisitione fauste investigata, testatur veterum saptentia [sic], qua docemur Moysen divinae philosophiae antistitem beatitudinis oram attigisse, quippe qui cum Deo sermonem habuerit, \& utriusque cognitionis clavem (supernaturalis nempe \& naturalis) divina sacrosancti spiritus assistentia \& illuminatione adeptus sit." 
Such a return of original pious wisdom, Fludd explained, occurred on the eve of a new age. He claimed, contradicting Libavius, that there would be a new period on earth, free from misery, just as the Rosicrucians taught:

We conclude that the brethren prophesy about future things, about the epoch and renovation of the world: they are seen to declare the nature of all things in a new language and through secret writings; they speak the truth, because they say that in our age every falsity will end..$^{134}$

In response to several of Libavius' specific objections, Fludd offered swift rebuttals: the Rosicrucians' prophecies agreed with Scripture, a new era was at hand, and the brethren possessed such original knowledge and qualities that they could foresee the future, probe beyond appearances, and express, like Adam in Paradise, the true nature of things. As they also announced the end of all falsity, Fludd understood them to be affirming all of the heterodox notions which Libavius had contested. Although Fludd did not explicitly refer to Libavius' denial of the possibility of earthly perfection, the fact that the new epoch will see true knowledge resurface-while it will also inaugurate the end of all deception-meant that perfection was possible before the end.

Fludd had previously judged that the new language with which the Rosicrucians could express nature's true reality was a gift from the Holy Spirit. ${ }^{135}$ As they could speak about what was beyond the surface of the world, they were in the vicinity of the clavis universalis. They possessed a new language rather than the Adamic or Enochian tongue, but it had qualities similar to those of Adam and Enoch - a conception that was particularly close to the notions expressed in the Confessio. ${ }^{136}$

All of this implied that the world would not descend into perdition, as Libavius had claimed, but that it would witness a time and place of happiness that was announced in ancient times: "[t]hat however [there] is some certain and undoubted place for human happiness in this world, investigated by many through long travel and due examination, the wisdom of the ancients testifies $[\ldots]]^{\prime \prime 37}$ It was for these and similar views, that Fludd was compelled to defend

134 Ibid., 15: "[...] colligimus quod fratres de rebus futuris, mundi periodo et renovatione vaticinentur: nova lingua \& scripturis arcanis naturam omnium rerum declarare videantur; veritatem loquantur, eo quod nostro, inquiunt, seculo desinet omnis falsitas."

135 Ibid., 14. Cf. above, n. 116.

136 Confessio, 56-57. $^{6}$.

137 Fludd, Apologia Compendiaria, 3-4: "Quod tamen sit certa quaedam \& indubitata faelici- 
himself before the English King James I, and to demonstrate that he was a faithful Anglican. ${ }^{138}$

New signs sent by God to the skies and inscribed in nature announced the imminent changes that were to take place on earth according to His plan. Fludd explained that " $[\mathrm{t}]$ he will of God and His ordinations can be clarified by the characters of the great Book of Nature and by the signs of the new stars without any help of the devil." 139 He suggested that one should not merely read Scripture, but also turn to the Book of Nature to learn about God. ${ }^{140}$ Theology was complemented by natural philosophy as creation, too, taught humans about the Creator. Both books, natural and scriptural, as well as the stars appearing in the heavens, could be studied to acquire insights into divinity.

In their Confessio, the Rosicrucians had claimed that their programme agreed with God's plan, which implied that they had access to knowledge of God, His will, and His plan, although this was not revealed to them through Scripture. Libavius later pointed out that the Rosicrucians believed that they had access to the divine will through such signs, and he had refuted such claims. ${ }^{141}$ This notion of being able to learn about God through nature was at odds with Lutheran orthodoxy and with the principle of sola scriptura, that is, with the idea that revelation can occur only through the incarnated Word (Christ) or the written Word (Scripture). More specifically, in some of his works Luther maintained that general or natural revelation-revelation about God through nature-is ultimately not sufficient, and he accepted solely revelation through Christ or Scripture (specific revelation). ${ }^{142}$ The idea that specifically

tatis humanae sedes in hoc mundo, \& à nonnullis longa peregrinatione \& debita inquisitione fauste investigata, testatur veterum saptentia [sic] [...]."

138 Fludd clarified his faithfulness in his "Declaratio Brevis," which he sent to King James I; see: Fludd, Declaratio Brevis, edited in: Huffman and Seelinger, "Robert Fludd's 'Declaratio Brevis' to James I," 69-92; and in: Huffman, Robert Fludd, 82-99.

139 Fludd, Apologia Compendiaria, 20: "Ultimo loco declaravimus. Quod voluntas Dei ejusque ordinationes, characteribus magni libri Naturae et signaculis novarum stellarum sine ullo Diaboli auxilio declarari possint." Fludd also added a long discussion of the devil and his works. These works, he claimed, might sometimes seem good, but always end in destruction and terror; see: ibid., $16-18$.

140 Cf. ibid., 20: "Scripturae divinae species luculenter satis explicantur. Characteres et literae ejusdem Scripturae insipiciuntur, et duplici impressione formari observantur, videlicet aut verbo Fiat, in creatione, aut sacrosancto Dei digito post creationem, quomodo insculptus est liber revelationis Maiestatis divinae, legesque Mosaicae in folijs lapideis."

141 Libavius, Analysis Confessionis, 3.

142 Cf. Luther, Disputatio Heidelbergae habita, WA 1, 361-362, theses 19-20. On this notion, and on God revealing himself only indirectly through Christ, see: Bradbury, Cross Theology, 6263 . 
the will of God can be learned from nature, as Fludd and the brethren implied, is contrary to Luther's distinction between Deus absconditus (the hidden God), and Deus revelatus (the revealed God). According to Luther, humans cannot have knowledge about divinity, certainly not from sources other than Scripture. In his On the Bondage of the Will (1525), a text on free will that was written against Erasmus, Luther explained that the will of God is "above us" (supernatural) and therefore unknown to us. Humans can have limited access to His will through Scripture, as He revealed Himself only through His Word, but they could neither acquire true and complete knowledge about His will nor learn about God's will through other means, because He would remain hidden to them (Deus absconditus). ${ }^{143}$ This doctrine of man's incapacity to know God was also formulated in the Lutheran Book of Concord. ${ }^{144}$

Viewed in this light, Fludd supported Rosicrucian notions that contradicted Libavius' orthodox Lutheranism: humans could learn about God's will not only through Scripture, but also through the study of nature. According to Fludd, natural philosophy and theology are intimately related: in both, students had to be illuminated by the Holy Spirit and both subjects will teach them about God. Fludd thus rejected the principles on the basis of which Libavius had dismissed the manifestos. But it was not only in Lutheranism that Adam's Fall was seen as having resulted in man's sinful nature; this was the case also according to the Anglican 42 Articles of religion (1553). According to this confessional text, also Pelagian notions as well as expectations of earthly perfection were to be condemned, and another earthly age was not to take place-which indicates the extent to which Fludd deviated also from his own confession. ${ }^{145}$

Another aspect of the Rosicrucian reformation that was refuted by Libavius was the reformation of all arts. Fludd agreed with the Rosicrucian judgement

143 Luther, De servo arbitrio, wA 18, 684-688, for example p. 686: "Satis est, nosse tantum, quo sit quaedam in Deo voluntas imperscrutabilis. Quod vero. Cur et quatenus illa velit, hoc prorsus non licet quaerere, optare, curare aut tangere, sed tantum timere et adorare"; ibid., 680: "Nos dicimus, ut iam antea diximus, de secreta illa voluntate maiestatis non esse disputandum et temeritatem humanam, quae perpetua perversitate, relictis necessariis, illam semper impetit et tentat, ese avocandam et retrahendam, ne occupet sese scrutandis illis secretis maiestatis, quae impossibile est attingere, ut quae habitet lucem inaccessibilem, teste Paulo." See also the English translation of On the Bondage of the Will in: Rupp and Watson, Luther and Erasmus: Free Will and Salvation, esp. 200-208.

144 Münster (ed.), Book of Concord, "Apologie der Konfession," in Die Bekenntnisschriften der Evangelisch-Lutherischen Kirche (1952), 150: "Voluimus enim significare, quod peccatum originis hos quoque morbos contineat: ignorationem Dei, contemptum Dei, vacare metu Dei et fiducia erga Deum, non posse diligere Deum. Haec sunt praecipua vitia naturae humanae, pugnantia proprie cum prima tabula Decalogi."

145 Dingel (ed.), "Anglikanische Artikel," (Forty-Two Articles), Die Bekenntnisschriften der reformierten Kirche (2010), articles ix, $\mathrm{x}$, xli. Pelagianism was also refuted in the later 39 articles of faith (1563), articles ix and $x$. 
that there was a clear need for such a reform, and he compared the healing of people to the healing of the arts. The brethren, according to the English physician, "cure the sick perfectly, because they propose means to humans, by which they can cure diseases." This, as we have just seen, was described by Fludd as a sign of their inspiration by the Holy Spirit. ${ }^{146}$ In the same manner, he argued while opposing Libavius, the brethren rightly undertook to cure the state of the arts. ${ }^{147}$ There could be found, according to Fludd, "a very great defect in all the arts that have flourished thus far in the schools." Among the arts to be cured or reformed, Fludd counted the defects of

natural philosophy, medicine, and alchemy, mathematics namely arithmetic, music, geometry, optics, and astrology, of morals and regarding the government of people like ethics, economy, politics, law, and in the final place there is the impediment of the theologians. ${ }^{148}$

Just like the manifestos themselves, Fludd described the Rosicrucian reformation not merely as the result of divine revelation granted to humans, but as a human effort. Libavius had denied that any improvement on earth could be effected by humans, but for Fludd the reformation meant the complete overhaul of traditional sciences. In him we find a figure not only promoting what Libavius detested (that is, Rosicrucian magic and philosophy in a new age), but also implicitly undermining Libavius' Lutheran orthodoxy, and rebuking Libavius' defence of the traditional university practice. In Fludd's opinion, the old sciences were inadequate because their remedy and reformation were not possible "without the uncreated chief doctor, that is, the Holy Spirit, and His servants."149 These arts were to be reformed so that they could be performed from divine inspiration, after the example of the brethren. Libavius would

146 Fludd, Apologia Compendiaria, 15: “[...] egros perfecte curent, nam media hominibus proponunt, quibus morbi sanari possunt." Cf. ibid., 14.

147 Ibid., 10: "At iam omnibus suspicionis latebris a D. Libavio peragratis, in illam etiam tandem haeresin fratres incidisse animadvertit, eo quod artium defectus reformare earumque languores medicare et corrigere polliciti sunt."

148 Ibid., 20-21: "Demonstravimus: Quod maximus sit defectus in omnibus fere artibus, quae hactenus in scholis viguerunt [...]. Defectus artium Physicarum videlicet Philosophiae naturalis, Medicinae, et Alchimiae: Mathematicarum nempe Arithmeticae, Musicae, Geometriae, Optices \& Astrologiae: Moralium et circa disciplinam gentium ut Ethices, Oeconomiae, Politiae, Iurisprudentiae, \& ultimo loco Theologorum impedimenta."

149 Ibid., 21: "Artium deficientium et tabe languescentium remedium correctionem reformationem quae non perficiuntur sine doctore principe increato spiritu nempe sancta, et ejus ministris, videlicet angelo bono, luce admirabili, Vrim \& Thumim, Epod dicta, aut sapiente seu propheta veridico." 
certainly have taken offence at these claims: he neither saw the Rosicrucian brethren as capable of curing diseases, nor did he consider the traditional arts to be in such a poor state as to require any kind of significant reform.

Of the arts to be reformed, Fludd took as his example theology, which in his view was in particularly poor shape. Theology was the "most outstanding of the arts," as indeed it had been in the medieval curriculum. But according to Fludd, scholars at universities only quarrelled over theological matters so that there was constant discord, "when one school of theologians would interpret [the meaning of the Bible] in this sense, another school in another sense," by which practice, he concluded, the biblical texts were corrupted. Just as Libavius had accused the brethren of teachings contrary to God and Scripture, Fludd in turn reproached academic scholars for pursuing a study of theology that, like all other sciences and arts, was not in accordance with either God or the Holy Spirit. This corrupted teaching could be carried out, Fludd remarked, without any suspicion of heresy, even though "it is the habit and custom of the Romans and papists to accuse those gravely of heresy, who do not adhere steadily to their religion." 150 Again we find the term "heresy" applied to established education, to scholars persisting in academic errors. ${ }^{151}$ In Fludd's view, impostors, university teachers, and Peripatetics alike would have no place in the new age after the Rosicrucian reformation.

While explaining his interpretation of the Rosicrucian manifestos, Fludd discussed many elements that were central to the Rosicrucian call for a reform, such as the ending of all falsity before the end of the world, the expectation of a new age, the claim of having insight into the true essences of nature, and the reform of universities. All of these were elements that had been dismissed by Libavius, but which in Fludd's response were used to explain that the brethren were pious men instructed by the Holy Spirit, that everything they said accorded with Scripture, and that their reform was not merely desirable but necessary.

While Libavius had rejected the Rosicrucians' medicine, in his Short Apology Fludd did not explicitly discuss this art, but he described the reform of the arts by medical analogy. ${ }^{152}$ Although the refutation of Paracelsianism took up such

\footnotetext{
150 Ibid., 10-11: "Et tamen videmus in scientiarum praestantissima Theologia sacrorum Bibliorum contextum in controversiam assidue vocari, cum una theologorum schola illum in hunc sensum, altera in alium interpretetur, et quaelibet quoslibet scripturarum locos difficilores suo more exponere et torquere solita sit, hocque sine ulla haeresis suspicione, quamvis Romanorum et Papistarum sit mos atque consuetudo, haeresis eos gravissime accusare, qui suae religioni constanter non adherent."

151 Cf. above, pp. 76-77, 134.

$15^{2}$ Fludd, Apologia Compendiaria, 22.
} 
a large portion of Libavius' Analysis, Fludd seemed not to consider it necessary to discuss this matter, and the name of Paracelsus is not mentioned in his text. Instead, Fludd primarily understood the Rosicrucians as harbingers of (returned) divine wisdom and magic. ${ }^{153}$ For Libavius, much of what is found in the manifestos was a new, heretical approach, linked to Paracelsus; for Fludd, it was the revival of a sacrosanct prisca philosophia that was finally being revived after centuries of pagan philosophy. When interpreting the manifestos, Fludd placed them in relation to traditions that have come to be known as Mosaic physics, the clavis universalis, and the philosophia perennis.

This is best understood in the context of Fludd's having to defend himself against suspicions of religious heterodoxy. In his Brief Declaration, submitted to King James I, Fludd explained that his Apologetic Tract, written in defence of the Rosicrucians, should not be interpreted as "religious innovation" or "heresy," because he, Fludd, remained a faithful Anglican. It therefore seems that keeping the contents of the Rosicrucian manifestos separate from the novelties of the Paracelsians was a quite deliberate strategy on his part, intended to remove any suspicion of heresy. He informed his King that in his Apology against Libavius' attack he had merely desired to revive the arts on the basis of ancient wisdom, and that he did not intend to deviate from orthodoxy. Like Anglicans, he continued, the Rosicrucian brethren self-identified as members of a reformed religion. His explanation to his King is in this regard consistent with his reply to Libavius: what he particularly appreciated about the Rosicrucians were their gifts of an original, true philosophy and ancient wisdom. ${ }^{154}$

\subsection{The Rosicrucian Manifestos Debated: Grick and Mögling}

A few years after the written discussion between Libavius and Fludd, two other authors took up their quills and examined the Rosicrucian case: Friedrich Grick (dates unknown) and Daniel Mögling. We have already been introduced to Mögling. Like him, Grick came from an academic background. He worked as a tutor at the Lutheran gymnasium in Altdorf near Nürnberg and claimed to be versed in law, theology, history, politics, medicine, and philosophy, to speak eleven languages and to understand fifteen. ${ }^{155} \mathrm{He}$ was keen on presenting himself as a well-taught scholar, versed in the studies of the ancients. This is how

153 For Fludd on ancient wisdom, see: Fludd, Declaratio Brevis, in: Huffman, Robert Fludd, 8299 .

154 Fludd, Declaratio Brevis, in: Huffman, Robert Fludd, 83-84.

155 Grick [Menapius], Copia der dritten Missiv, $\mathrm{C}^{\mathrm{v}}-\mathrm{C}_{7}{ }^{\mathrm{r}}$. 
he portrayed himself in numerous writings, of which many were on the topic of Rosicrucianism published under two pseudonyms, Menapius and Irenaeus Agnostus. That the author behind these pseudonyms was Grick was already suggested by Widemann when he reiterated the conclusions of a J. Oswald from Montbéliard. In his Sylva scientiarum (Collection of the Sciences), Widemann expressed the following remark: "Menapius, usually named Friderich Grickh, is Irenaeus Agnostus. A malicious, treacherous, evil man." ${ }^{156}$ As Grick had criticised the manifestos in several of his texts, this brief description speaks to the author's own sentiments in favour of Rosicrucianism.

The two opponents, Mögling and Grick, discussed the Rosicrucian case in several of their writings. In relation to his pamphlet discussion with Mögling, especially relevant is Grick's Supply of Letters written under the pseudonym Menapius, which included three letters in which he analysed and attacked the Rosicrucian brethren and their studies. The first is dated 3 June 1617 , which was followed by a second letter of ${ }_{15}$ July 1617 , and a third letter that is undated. ${ }^{157}$ These letters were appended to his Fortress of Science, which was written under the pseudonym Irenaeus Agnostus and dated 13 August 1617. In the Fortress, Grick presented himself as a brother of the Rose Cross, but the text was an obvious parody of the Rosicrucian society. The difference in pseudonym is important, because it seems that Grick's critical writings are published under the pseudonym Menapius, and the seemingly optimistic texts are published under the pseudonym Agnostus. ${ }^{158}$

The following year, 1618, Mögling published his Flourishing Rose under the pseudonym Florentinus de Valentia as a reply to the three letters of Grick's Sup$p l y .{ }^{159}$ Mögling, too, was aware of the true identity of Menapius, as he addressed his responses to "F.G. Menapius" and referred to "Fredericus G," clearly

${ }_{15} 6$ Widemann, Sylva scientiarum, 723: "Menapius, sonsten Friderick Grickh genanndtt, ist Irenaeus Agnostus. Ein arglistiger ausgestochener böser Mensch," cited in: Gilly, Johann Valentin Andreae, 51.

157 Grick [Menapius], Copia literarum, copia der andern Missiv, Copia der dritten Missiv (1617). To distinguish these three texts from the Fortalitium scientiae, these letters will be referred to separately.

$15^{8}$ Grick [Agnostus], Fortalitium scientiae, Aviiir. In effect, Grick, as Agnostus, claimed to be the notary of the Rosicrucians in numerous of his writings, while often at the same time implicitly mocking them and hinting that the fraternity was a sham. Grick's numerous tracts, and his seemingly twofold attitude towards the Rosicrucians in particular, are highly interesting and still require careful analysis.

159 Mögling [Florentinus de Valentia], Rosa Florescens contra F.G. Menapii calumnias. Das ist: Kurtzer Bericht und Widerantwort/ auff die sub dato 2 Iunii 1617 ex agro Norico in Latein/ und dan folgendes 15 Julii obgedachtes Jahr Teutsch publicirte unbedachte calumnias, F.G. Menapii, Wider die Rosencreutzische Societet. 
signifying Friedrich Grick Menapius. To analyse this discussion, again particular attention will be paid to the writings where there is a clear dialogic link between a commentary and a response.

\section{Grick: Protecting State and Learning}

Grick, writing as Menapius, presented himself as an anti-Rosicrucian scholar, and in his Supply of Letters he fulminated against the Rosicrucian manifestos. Like Libavius, he did not primarily dispute the existence of the fraternity; his criticism was directed rather against the contents of the manifestos, and notably the promises of change. Before addressing the topic of the general reformation specifically, he made his sentiments about the Rosicrucian fraternity explicit from the start, in remarkably unsparing words. He suggested that the brethren were merely "a bunch of idle men," who with their "fantastical writings" were "abusing the work of printers." He compared them with "Thessalonian nigromantics," "Chaldean deceivers," and "other incarnated devils." ${ }^{160} \mathrm{He}$ mistrusted the brethren's promises, condemned their "monstrous crimes,"161 and concluded that "in any case I am unable to make any positive pronouncement about you."162 Unlike many of his contemporaries, he explained, he decided not to be fooled by the Rosicrucians' optimism. The brethren pretended to be virtuous and trustworthy, but "if you are virtuous and honest men, why have you so far given cause for suspicion about you to good and learned men?"163 The brethren were vain and deceptive, and as a corrective Grick declared himself willing to instruct them in the fifteen languages he claimed to understand and the eleven he professed to speak. ${ }^{164}$ But what had given rise to such a fierce judgement and suspicion?

16o Grick [Menapius], Copia literarum, B3 $3^{\mathrm{v}}$ : “[...] si non manipulus otiosorum hominum estis, qui [...] Typographorum opera abutentes, nequitia simpliciores ludificandi, et naso suspendendi phantasticis vestris scriptis veteratorie laboratis: certe vel recens exortum genus stellionum, ac verberorum, vel nigromanticos Thessalos, et Chaldaeos oculorum praestictores, vel aliquos incarnatos Diabolos, qui impossibilia humano ingenio praestare dolose sat agitis, vos esse oportet."

161 Ibid., B3 $3^{\text {r: }}$ "Eiusmodi invidiae aculeos, si ullus unquam, certe jam me sentire necesse est, cum me vobis opponam, qui non contemptam solum, ac imperitam multitudinem, sed etiam non paucos ex majorum maleficiis vestris dudum effascinastis."

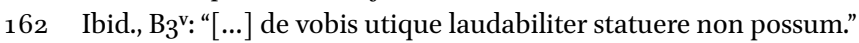

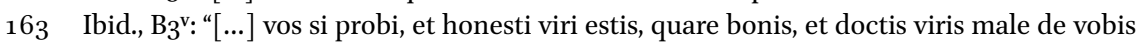
suspicandi causam hactenus reliquistis?"

164 Ibid., $\mathrm{C}_{7}^{\text {r: }}$ :In den sprachen aber/ derer ich funffzehen stehe/ und eilff wol practiciren, und reden kan/ wolte ich euch noch zurathen geben. Derwegen seind ewere imaginationes groß/aber vergeblich/ und ein betrug [...]." 
Central to Grick's mistrust was the primary impetus behind the manifestos: the Rosicrucians' call for reform. He began by swiftly debunking the millenarian imagery that had accompanied it. Like Libavius, he mistrusted the Rosicrucians' hopeful expectations about a new earthly age: "How do you know that before the world's ending everything must come to perfection like that at the time when our first parents were still in a state of integrity?"165 He pointed out that the teachings of the Bible told otherwise: Isaiah teaches that the Final Days are imminent, and that they will bring fear, destruction, death by fire, and the Lord's wrath. ${ }^{166}$ According to Grick, the end of the world will be ushered in by destruction, and it would not be preceded by an age of perfection, contrary to what the Rosicrucians claimed.

But Grick's Supply was not overly preoccupied with religious incongruities or the millenarian imagery of the Rosicrucian manifestos, nor did he compare the manifestos to biblical passages at any length. He studied extensively the Rosicrucians' plans for reform in relation to something Libavius had neglected, namely the state of affairs within society and the situation in which the empire found itself. The manifestos had mentioned that a new empire would be established in the future age. Grick took this claim as an announcement of societal reform to be effected by the Rosicrucians. In Grick's view, political reform was a necessary measure, as the empire was in dire need of it. He observed the world to be in a terrible state, with misery and poverty abounding:

Cities of the empire, with few exceptions, look like only carcasses of these cities that flourished when the state was in a better shape [...]. Farmers and citizens groan everywhere under heavy burdens. ${ }^{167}$

Grick's observation about the decline of once flourishing cities was made shortly before the outbreak of the Thirty Years' War in 1618, when religious tensions had already become increasingly virulent, people lived in dire poverty, and the plague circulated in Europe. The Rosicrucians, he observed, had promised to relieve the world from its hardship and the citizens and peasants from their misery. According to him, the brethren had given the impression that they

165 Ibid., $\mathrm{C}^{\mathrm{v}}-\mathrm{C} 6^{\mathrm{r}}$ : "Als habe ich mich durch meine curiositet, und fürwiz dahin bewegen lassen/ an euch eine frag zuthun/ nemlich/ woher ihr wisset/ daß vor der Welt end alles zu einer solchen perfection, gleich wie es zur zeit/ da unsere erste Eltern noch in statu integritatis gewesen/ kommen müsse?"

166 Ibid., C6r. See, for example, Isaiah 23 and 24.

167 Grick [Menapius], Copia literarum, B4": "Urbes Imperii, praeter paucas, videntur tantum esse cadavera earum urbium, quae Republica melius constituta floruerunt [...]. Agricolae vero, \& cives ubique sub gravissimis oneribus gemunt." 
would help those in need and distress - a promise he would have applauded had he not believed that these were objectives the Rosicrucians were doing nothing to secure. According to Grick, there was no evidence to show that the Rosicrucians were actually involved anywhere in alleviating suffering:

But if you truly are those highest and admirable masters of the arts, as you love to be called, and gracious heroes and apostolic grandees of the sublunary nature [...], in this general state of the world, which because of the perturbation of all things is tired and sick, why do you not do something about it, and rush forward with your most novel and unexpected assistance?168

It was precisely the promise of improvement and evidence of the lack of it that Grick considered the highest deception and which had provoked his suspicion. While the world was in need, the Rosicrucians stood idly by. He called the Rosicrucians "impostors" for keeping their names private and conceiling themselves from those who needed them: "Why did you shrink away from civil society through so many centuries? Why, I repeat, if you are not impostors, had it benefited you to have shunned the eyes and ears of humans through such a long course of time? Why?"169 Grick reminded his readers that the Rosicrucians claimed that their society had already existed for many decades: Christian Rosencreutz had founded it in the early fifteenth century, and when he died at the age of 106 the brethren had remained hidden for at least another one hundred and twenty years. All this time, Grick pointed out, they had neither revealed themselves nor given their aid to the world, even though the world was festering. ${ }^{170}$

Grick complained that even after they had gone public, and had promised their support publicly, they merely wandered anonymously from place to place. ${ }^{171}$ They bragged about their evangelical virtues while demonstrating none:

168 Ibid., $B 4^{\mathrm{r}}-\mathrm{B} 4^{\mathrm{v}}$ : "At vero si summi illi et admirabiles artium Antitistes [sic], ut appellari gaudetis, atque gratiosi Heroës, Naturae sublunaris Megistanes Apostolici estis [...], cur non in hac omnium rerum perturbatione fessis, \& exulceratis communibus mundi rebus aliquid opis fertis, vestroque novissimo, et insperato auxilio, et adjumento occurritis?"

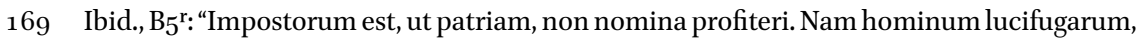
nulliusque Reipublicae civium nota est, se abnegare, et natale solum abscondere [...]. Cur enim a civili societate per tot saecula abhorruistis? Quid, inquam, si impostores non estis, vobis profuit, per tantum temporis curriculum oculos, auresque hominum vitasse? Quid?"

170 Ibid., $\mathrm{B}^{\mathrm{v}}$.

171 Ibid., B4 $4^{\mathrm{v}}-\mathrm{B}_{5}^{\mathrm{r}}$; cf. Fama, 106. 
But who possesses evangelical perfection, about which you boast (like those who have transgressed into the heresy of the Anabaptists), liberates the oppressed from destruction and restores the sick, helps those who are lost, lifts up the poor, raises those who have fallen. But so far you have attended no one in any such condition: you have given refuge to no one, you have brought aid to no one, you extended relief to no one, but you brought danger to many. ${ }^{172}$

The brethren, in Grick's view, were just as heretical as the Anabaptists. He probably had in mind Anabaptist communities such as those in Münster, Augsburg, and Strasbourg. Since such communities attracted poor peasants, and the Anabaptists recommended poverty as a virtue, the conditions within them were hazardous and brought solace to none. Like the Anabaptists, Grick argued, the Rosicrucians promised reform but brought about the opposite.

Apart from their misguided proclamations promising to reform the state, Grick argued that the Rosicrucians' intention to reform the arts and sciences was equally to be rejected, albeit for different reasons. Like Libavius, he considered the Rosicrucians' plans for change in the academies and their replacement of traditional sciences by their own thought to be not merely deceptive but even destructive. He aimed to prove that the Rosicrucian reformation of established learning was undesirable for the two reasons Libavius had also mentioned: the good state of the current arts and the poor alternative of the brethren. More so even than Libavius, Grick emphasised the superiority of the arts and of the contributions of past scientists and artists. Why, he asked, would one abandon the contemporary arts? ${ }^{173}$ Were academies and schools not better off precisely "because they were not guided by your council and authority, namely by rotten and foolish tittle-tattle and tasteless madness?"174

172 Grick [Menapius], Copia literarum, B4v: "Atqui Evangelicae perfectionis est, de qua vos gloriamini, ut ii, qui in Anabaptistarum haeresin praevaricati sunt, vindicare oppressos $\mathrm{ab}$ interitu, languidos recreare, perditis suqvenire [sic], levare pauperes, jacentes erigere. At vos nemini hactenus in casu adfuistis: nemini refugium subministrastis: nemini suppetias tulistis: nemini subsidium porrexistis: nonnullius periculum concurristis."

173 Ibid., B5 $5^{\mathrm{v}-B 6} 6^{\mathrm{r}}$ " "Vani profecto est illud narrare: stulti credere. Etenim si non vappa [sic] non flagriones compitalitii estis, dicite mihi, quid vel Architectonicae, nostro aevo desit, vel Manganariae, Mechanopaeoticae, Scansoriae, Tractoriae, Organopaeoticae, Thaumanturgicae, Sphaeropae, Automatopaeoticae, Arithmeticae, Geometriae, Navilculariae, Statuariae, Fusoriae, Caelaturae?"

174 Ibid., $\mathrm{B}_{5}{ }^{\mathrm{r}}-\mathrm{B}_{5}$ : "An scholae et Academiae faustis auspiciis Sapientissimorum Principum, ac Gubernatorum introductae et apertae, illustrique munificentia, et liberalitate eorum auctae, et amplificatae hucusque non extiterunt scholae et Academiae, ex quibus tanquam fontibus ora sua rigarunt, virtutisque suae fundamenta hauserunt plerique ex iis, 
The contemporary sciences and arts, Grick believed, needed no radical change, and to suggest otherwise was pure deception. Universities and schools, he estimated, were already thriving at a high level of excellence:

Tell me, what do you wish to teach [Johannes] Reuchlin in Hebrew, [Guillaume] Budé in Greek, [Desiderius] Erasmus in Latin, [Pierre de] Ronsard in his vernacular language, [Justus] Lipsius in history, [Giovanni della] Casa [the author of the Galateo] in the elegance of polite behaviour, Hippolytus a Collibus [i.e., Johann Werner Gebhard] in politics, [Marquardus] Freherus in antiquity, [Nicolaus] Vigelius in Justian civil law, [Andreas] Gailius in matters of the Imperial Chamber, [Julius] Caesar Scaliger in physics, [Jacob] Scheck in logics, [Peter] Fonseca in metaphysics, [Antoine] Muret in oratory, [Iacobo] Sannazari in poetics, [Nicodemus] Frischlin in grammar, Tycho Brahe in mathematics, Orlando [de Lasses] in music, [Albrecht] Dürer in painting, Salvador in athletics, ${ }^{175}$ [Domenico] Fontana in construction?176

Did the brethren truly propose to abandon these wonderful sciences and arts and neglect all advancements and achievements made by these scholars and artists? Grick did not mention great recent authors in chemistry and medicine, domains that were crucial to the Rosicrucian followers, but which Grick presumably deemed inferior to these ancient and humanist arts. The brethren, he claimed, aimed to neglect and destroy scientific contributions of the ancients and humanists rather than continuing their accomplishments. But these people had only been able to scratch the surface of the knowledge of nature: "everyone states, and truth confirms it, that the knowledge of natural things has been surveyed by mortals only in a very small portion." This should not imply

qui in Germania, et vicinis gentibus cum laude praeterito, ac praesenti tempore praefuerunt, ac praesunt Ecclesiis, et Reipublicae partim negotiis, et occupationibus distinentur, partim gravissimorum munerum procuratione superiori aetate districti fuerunt, quia vestro consilio, et authoritate non regebantur, putidis videlicet, et stultis blateramentis, ac deliriis insulfissimis?"

175 This may be Petrus Fabrus Sanlorianus, the author of the Agonisticon.

${ }_{176}$ Grick [Menapius], Copia literarum, B6r: "Dicite mihi, quid Reuchlinum in Hebraica, Budaeum in Graeca, Erasmum in Latina, Ronsardum in vernacula sua linguae, Lipsium in Historia, Casam in morum elegantia, Hippolitum à Collibus in politica, Freherum in Antiquitate, Vigelium in Jure civili Justinianeo, Gailium in practica Camerae Imperialis, Caesarem Scaligerum in Physica, Schekium in Logica, Fonsecam in Metaphysica, Muretum in Oratoria, Sannazarium in Poetica, Frischlinum in Grammatica, Tychonem Brahe in Mathesi, Orlandum in Musica, Dürerum in Pictura, Salvadorem in Athletica, Dominicum Fontana in Fabrica docere voluissetis?" 
that they should be destroyed. Quite to the contrary, Grick argued, we should build upon them, and "therefore it is all the less opportune that you eagerly strive and endeavour to knock from our hands the discoveries of the ancients and force upon us your opinions that are so averse to nature herself."177 Much was still to be discovered in nature, but in Grick's view the way forward was not the destruction of past investigations and their replacement with something entirely unnatural.

Grick's second reason for dismissing the Rosicrucian reformation of the sciences was their alternative which, like Libavius, he believed was based on magic. With such an unnatural substitute, the brethren could not but arouse the suspicion of good scholars. In his second letter, the Copia der andern Missiv, Grick emphasised that the purity of the academies and schools was at risk because of the Rosicrucian fables, stories, and fantasies; as an example whereof he gave a mocking description of the fraternity's habitat, which he believed was a castle. Grick described the castle as invisible and surrounded by water. It was enchanted and entirely shrouded by clouds, through which no one could penetrate. ${ }^{178}$ Only when one passed through high gates, having surrendered one's garment to a young woman, did the clouds vanish and the castle appear. ${ }^{179} \mathrm{But}$ how could the sciences and arts possibly benefit from such fables: "I cannot see whether now through such and similar fantastical chimaeras and dreams churches and schools are built: But I pray to God for all high authority, that they will find guidance and mercy, to maintain and protect the truth from all devilish sham and tricks."180 Grick, like Libavius, desired to protect established education as well as scientific developments from a fraternity that he believed to be not only unorthodox but outright dangerous in its intellectual ambitions. In his view, only madmen would dismiss everything that had been practiced so far, while boasting to know everything better. Such was, he claimed, the very business of impostors. ${ }^{181}$

177 Ibid., B6 ${ }^{\mathrm{r}}-\mathrm{B} 6^{\mathrm{v}}$ : "Omnes fatentur, et veritas suffragatur, naturalium rerum scientiam ex minima sua parte mortalibus perspectam esse. Itaque eo minus ferendum est, vos et ut veterum inventa nobis ex manibus excutiatis, et vestras ab ipsa natura abhorrentes opiniones obtrudatis, cupidissime contendere, atque moliri."

178 Ibid., $\mathrm{C}_{3}^{\mathrm{v}}$.

179 Ibid., Ciiiv-Ciiiiv. This specific castle did not have its origin in Eglin, who described the Rosicrucian home differently.

180 Ibid., Ciiiiv: "Ob nun durch solche/ und dergleichen fantastische chimaeras, und traumthädungen/ Kirchen und Schulen erbauwet werden/ kan ich nicht sehen: Aber ich bitte Gott für alle hohe Obrigkeit/ daß sie Raht unnd gnade erfinden/ die warheit für allem Teuffels betrug und list zu handthaben unnd zubeschirmen."

181 Ibid., B5: “[...] nullamque artem, et disciplinam esse, divinam, naturalem, artificialem, 
The Rosicrucians' profession, Grick explained, had little to do with science, but rather with bad magic: "It is typical of bad magicians, to explain all things through enigmas and through certain ceremonies" - hinting at the term "ceremonial magic" that came about by devilish influences. ${ }^{182}$ When attributing such magic to the Rosicrucians, Grick took them for deceiving revolutionaries rather than honest reformers. He asked the Rosicrucians: "If the things you do are honourable and useful to common life, why do you not communicate them to everyone, without uncertainties and wrappings?"183 In Grick's view, because the Rosicrucians merely told fabricated stories rather than build their views on philosophy, they were bad magicians. ${ }^{184}$ University-based teaching could not be dismissed because it at least had its basis in philosophy and its tradition.

The Rosicrucians had described neither ceremonies nor their activities as magical, nor had they provided a depiction of their castle. Like Libavius, Grick considered the brethren to be involved with diabolical magic, but unlike Libavius, in support of this view he offered only dubious fables originating from unnamed sources. In the Supply of Letters, he assembled a number of stories that he considered to be as magical and imaginary as the Rosicrucian one. One of these discussed Albertus Magnus; another told about a young man from Sicily who took a swim; and a third concerned the father of Cardano. ${ }^{185} \mathrm{~A}$ fourth story featured Paracelsus, whom Grick compared to "the drain of Satan." Paracelsus, he informed his reader, had taught in a public lecture in Basel that the relationship of the Christians to God was unperturbed, that besides the worship of God one could also engage with daemons, and that he taught about "the magical exorcism of diseases." 186 Grick claimed that these were practices that could only be performed by inspiration from the devil rather than by divine

et humanam [...], quae non vestra reformatione indigeant?"; ibid., B5 $5^{\mathrm{r}: ~ " I m p o s t o r u m ~ e s t, ~}$ affirmare contra omnes omnium disciplinarum et artium Magistros, nullam scientiam hactenus recte esse traditam, nec tamen melius quid proffere, et errantes in viam regiam reducere."

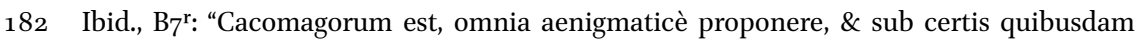
ceremoniis."

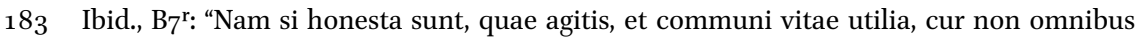
absque ambagibus, \& involucris communicatis?"

184 Ibid., B7 $7^{\text {r: }}$ "Qui faciunt, \& exhibent, quae in nulla philosophia fundamentum habent, Gacomagi sunt."

185 Grick [Menapius], Copia literarum, $\mathrm{B}^{\mathrm{v}}-\mathrm{C}_{3}{ }^{\mathrm{r}}$.

186 Ibid., $B 7^{\mathrm{v}}-\mathrm{B} 8$ r: "Et mancipium istud quidem, atque cloaca Sathanae, Paracelsus, cum Basileae publicè, in nescio cijus authoris praelectione, seu explicatione, profiteretur, atque doceret, Christano homini illaesa $\varepsilon \dot{\sigma} \varepsilon_{\beta} \varepsilon\llcorner\alpha$, citraque debiti erga Deum cultus maculam, Daemonis, tanquam latronis, ope, opera, \& consilio uti divinitus permissus esse, de incantationibus quoque, \& exorcismis morborum magicit [sic; magicis] agere caepit." 
inspiration, and he suspected Paracelsus of being in league with the devil. He argued that Paracelsus worked according to the motto: "If God does not want to help, the devil will help," suggesting that God did not want to be involved in such chimeras, but that the devil was eager to support Paracelsus, and by implication also the Rosicrucians' magical tricks. ${ }^{187}$

According to Grick, the Rosicrucian manifestos were similar to such invented fables: they were inspired by magic, devilish, and were therefore to be dismissed. He did not however provide a detailed explanation-quite like his mocking texts under the pseudonym Agnostus-but rejected the manifestos only by association. Grick perhaps associated the manifestos with the Ars Notoria, or the Notory Art of Solomon. The Ars Notoria is a grimoire consisting of a collection of orations and prayers, and is intended to help in eloquence, learning, and remembering through the help of angels. It includes instructions on how to pronounce magical words and to perform magical ceremonies. Its oldest edition originates from the thirteenth century, but several editions followed in the early modern period, including one that was edited by Agrippa von Nettesheim. ${ }^{188}$ Grick later referred to this text in his seemingly optimistic Fortress of Science - to which the Supply of Letters was appended-where he associated King Solomon of the Ars Notoria with the Rosicrucian fraternity. 189

The Rosicrucian manifestos, according to Grick, posed a clear threat not only to society at large but also to the intellectual community in particular. The Rosicrucian reform plans had roused him to compose his harsh criticism of the manifestos. Unlike Libavius, he did not respond to the Rosicrucian general reformation from the standpoint of an orthodox Lutheran, but rather as a citizen and an academic. Religiously, he believed they were radicals, mingling heresy with false hopes about a future perfect age. Politically and socially, the Rosicrucians' reformation was partly intangible and partly deceptive, because they never fully revealed themselves and extended help to none. Academically, Grick worried about dubious alternatives that challenged the academic establishment, but only by associating the manifestos with magical fantasies.

\section{Mögling: Academic Reform and Theosophy}

Grick's withering public judgement on the Rosicrucians was soon met with a response from Mögling, whose Flourishing Rose (1618) presented his arguments against Grick's scathing letters and "inconsiderate slanders." ${ }^{190}$ He explicitly

187 Ibid., B8 ${ }^{\text {r: }}$ "Will GOtt nicht helffen, so helffe der Teuffel."

188 See, for example, the English translation by Turner, Ars Notoria (1657).

189 Grick [Agnostus], Fortalitium Scientiae, Aviiir ${ }^{r}$.

190 Mögling [Florentinus de Valentia], Rosa Florescens. 
referred to the author of the first two letters as "Fredericus G.," or Menapius, and also mentioned another German text by Grick, although not by name, which in contents corresponded to the third letter of Grick's Supply. ${ }^{191}$ Mögling was faced with a similar problem as that which had previously confronted Fludd: on the one hand, he had to demonstrate the falsity of his opponent's claims; on the other hand, he needed to explain the true aim and merit of the Rosicrucian brethren and their manifestos. The obvious contempt in the tone of Grick's letters about the Rosicrucians had captured the attention of the theosopher. To devalue his opponent's examination, he began in a similar manner as Grick himself had done, namely by attacking him ad hominem. He addressed Grick's scornful abuses, asking whether "this should be the judgement of a Christian and a learned man - who could recognise it as such?"192 The speed with which Grick issued his letters "with such baseless slander," was discreditable, whereas "good honourable people," Mögling continued, "would not be so swiftly taken by wrath, and would wait with patience and hope for the time" that the Rosicrucians revealed themselves. ${ }^{193}$

Mögling addressed Grick's arguments against the Rosicrucian reformation of society and science. Perhaps the most difficult argument for Mögling to defend against was Grick's accusation that, in the midst of the "turbulent state of the empire," the Rosicrucians seemingly failed to support their fellow citizens. ${ }^{194}$ This was obviously a problematic issue for Mögling: on the eve of the Thirty Years' War, the country was clearly in despair, without any evidence of discernable help coming from the fraternity. According to Mögling, however, the brethren did help and support those in need, since "they help daily with teaching and admonishing both in writing as in person and orally to the innocent godloving." ${ }^{195}$ Despite Grick's insinuations, the brethren offered their knowledge to the people.

191 Ibid., Aiir ${ }^{\mathrm{r}}-\mathrm{Aii}^{\mathrm{v}}$.

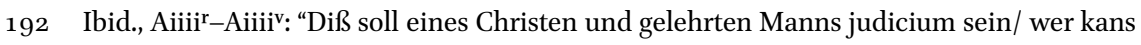
darvor erkennen?"

193 Ibid., Aiiiiv: "In deiner ersten Epistel woltestu hoch angesehen und gelehrt sein. Jetzt da die Fratres nicht fluck sich eröffnen/ kombstu mit solchem fundament und grundlosen calumniis ganz colerisch auffgezogen/ vermeinest alles über einen hauffen zuwerffen/das beste ist/ das viel gute Ehrlicher Leut sich den zorn so jehe nit lassen übernemmen/ und in gedult und hoffnung der zeit erwarten."

194 Ibid., Avv: "Es fragt Menapius, gleich wie alle unzeitige Richter/ warumb die Fratres, weil sie je turbulentum Imperii statum vor augen sehen/ Christlichen potentaten/ auch armen betrangten Leuten nicht persönlich zu hülff kommen." Cf. Grick [Menapius], Copia literarum, $\mathrm{B}_{4}^{\mathrm{v}}$.

195 Mögling [Florentinus de Valentia], Rosa Florescens, Avir: “[...] Sie hilfft täglich mit lehren 
The problem was, Mögling explained, that the majority of humans did not want to be helped, thereby shifting the problem from the Rosicrucians to society: "People are too impious, and they neither want to be directed nor guided."196 Mögling did not really address Grick's reproach regarding the Rosicrucians' lack of practical help, but reversed the issue and instead blamed the majority for not being receptive to the Rosicrucians' support. According to him, times were hard and dangerous, people impious, and they were liable to use their capabilities to cause harm rather than good. ${ }^{197}$ It was from this enmity of the masses that the brethren hid themselves and concealed their names, helping only anonymously and in the background. Moreover, Mögling maintained, Grick was in no position to berate the Rosicrucians for their caution, as he himself had also used a pseudonym behind which he was hiding. 198

Mögling expatiated at greater length on the subject of the Rosicrucians' intellectual contributions and their reformation of the arts and sciences. The reform of the arts was an element of the Rosicrucian reformation that was discussed at length by all four authors, Libavius, Fludd, Grick, and Mögling. Grick, Mögling recalled, had concluded that many arts were perfect and needed no reformation. ${ }^{199}$ But was this really true?

und vermanen so wol Schrifftlich als bey treuherzigen Gottliebenden beywesentlich und mündlich $[\ldots] . "$

196 Ibid., Avir: "[...] das man aber mit einem offnen auffzug jederman soll vor augen ziehen und gleichsam ein Jahrmarck darauß machen/ ist nog der zeit unrahtsam/die Leut sein zu Gottloß/ wollen sich weder weisen noch leyden lassen [...]."

197 Ibid., Avir: "[...] was jedem in seinem kram daugte/ das nemb er/ und braucht er eben so bald zu unzucht/ schäd/ lastern/ und Weltlichen wollüsten/ als zur Ehr Gottes."

198 Ibid., Avir: "Das die Brüder hin unnd wider Reisen/ macht sie darumb nit zu betriegern und Landverrähtern/ sintemal all ihr pereginationes dem nechsten zu nuz und gut angesehen/ und schadt gar nicht/ ob sie ihr Namen unnd Vatterland nit jedem bekandt machen/ in erachtung es noch gefehrlich/ unnd hat sich Menapius eben solches Salviergriffs (dessen er sie beschultiget) auch gebraucht: De zween Buchstaben F.G. bedeuten zwar seinen Tauff-und Zunamen/ wenn und wannen her er aber sey/ bedunckt ihn öffentlich zu setzen (wie billig) unrahtsam."

199 Ibid., Aviir: "Er vermeint zu viel geredt sein/ das sie sprechen/ die reformation sey hoch von nöten/ und bringt zum Exemple herfür Manganariam, Mechanopaeoticam, Scansoriam, Fractoriam, Organopęoticam, Thaumauturgicam, Sphaeropoeam, Automatopaeoticam, Arithmeticam, Geometriam, Naviculariam, Statuarim, Fusoriam, Caelaturam, etc. welche er alle vermeint gar perfet und in höchssten sein." Cf. Grick [Menapius], Copia literarum, $B 6^{r}$. 
Where are the great works, the artistic [künstliche] attempts of Archimedes; who can be found among the hundreds who could produce the same, if he already believes to know the art? Who can prepare for me such a heaven, or give me its measure and melody, about which the poet Claudianus speaks?200 [...] Who has mastered in architecture the art of copying the Collossus of Rhodes? Where is the wooden flying dove of Archytas? Where is the [mechanical] head of Roger Bacon and of Albert the Great? Where is the mathematics of Boethius? Where are the artistic mirrors and the optical masterworks? I will keep silent about the fire burning ceaselessly, about perpetual movement, and the like. ${ }^{201}$

There may be good scholars about, but the ancients and humanists mentioned by Grick had not brought forward anything as excellent as had these successful masters of the past. The head of Roger Bacon refers to his brazen head, a mechanical head he allegedly had created. The artistic mirrors are mirrors used for optical purposes in catoptrics, which was also studied by Roger Bacon. A work about the perpetuum mobile is attributed to Mögling himself. ${ }^{202}$ Even among the outstanding figures mentioned by Grick, none were capable of performing or even understanding the contributions of these artisans and inventors of the past.

Grick and Mögling had different notions of "arts." Grick referred primarily to academic and humanist sciences, whereas Mögling had automata and mechanical technologies in mind that were neglected by Grick. Both, however, kept silent about alchemy and medicine. Mögling agreed with Grick that there was still much that was to be discovered, but argued that much was also lost, and this was why the Rosicrucians aimed to reform the arts in the first place. In this context, he referred to Fludd's defence of the Rosicrucians against Libavius and his support of their reform of the arts:

200 Mögling cited: "Jupiter in parvo cum cerneret aethera vitro, Risit, \& ad superos talia dicta dedit. Huccine mortalis progressa potentia curae? Jam meus in fragili luditur orbe labor," which concerns the sphere of Archimedes that could represent the movements of the heavenly bodies.

201 Mögling [Florentinus de Valentia], Rosa Florescens, Aviir-Aviiv: "Wo bleiben die grossen werck/ die künstliche conatus Archimedis, wer ist unter hunderten/ der d'gleichen darff ins werck richten/ ob er schon vermeint er wisse die kunst. Wer kan mir ein solchen Himmel zurichten/ oder die ration unnd weiß geben/ davond Claudianus poëta schreibt [...]. Wer ist in Architectura so künstlich/ der den Colossum zu Rhodis nach machte? Wo bleibt die hölzin fliegende Taub Architae? Wo das haupt Rogeri Baconis \& Alberti Magni? Wo die Mathematica Boëtii? Wo die künstliche Spiegel und Optica artificia? Will alhie geschweigen Ignem indefinenter ardentem, motum perennem und dergleichen [...]."

$2 \mathrm{O} 2$ Mögling [Valerius Saledinus], Perpetuum mobile, das ist, immerwehrende Bewegung (1625). 
What can be found in arithmetics? Is not in algebra still much hidden? Who knows today how to number in a Pythagorean manner until the knowledge of God? Who knows the right use of rhythmomachy?203 Who knows the use and composition of the Pythagorean wheels, about which so far so many books full of sophistical deception have been written under the name of "Nomandy" and others, as Robert Fludd testifies in his Apology against Libavius. ${ }^{204}$

Because all such inventions were lost did the Rosicrucians aim to improve the arts and sciences. In relation to this, Mögling drew on the ancient musica universalis, expressed by Pythagoras, discussed by Boethius to whom he had earlier referred, and recently popularised by Fludd. Fludd is well known for having understood the macrocosm as a universe in harmony, with musical consonances and (mystical) mathematical relations set in place by God. The Rosicrucians had implicitly referred to this when arguing that the microcosm was in the same tone and melody as the macrocosm. ${ }^{205}$ Mögling, too, believed that there was a musical harmony between all creatures in the universe, from which followed the sympathy and antipathy between them, and that this harmony could be studied. ${ }^{206}$

To the claim by Grick that the Rosicrucians "despise and destroy all universities, academies, learned doctors, and teachers," Mögling replied that their writings proved the very opposite. ${ }^{207}$ They refuted only worn-out doctrines

203 Rhythmomachy, or Rithmomachia, was an early European mathematical board game, which supposedly was used to teach Boethian mathematics. On this game, see: Moyer, Fulke and Lever, The Philosophers' Game.

204 Mögling [Florentinus de Valentia], Rosa Florescens, Aviiv: "Was ist in Arithmeticis? Ist nit in Algebrâ noch vil verborgen? Wer weiß jetzund die weiß auff Pytagorisch biß zur erkentnuß Gottes zu numerirn? Wer weiß den rechten Usum Rythmomachiae? Wer weiß den Usum \& compositionem Pythagoricae rotae, davon doch so viel Sophistisches betrugs völliger Bücher bißhero geschrieben sub Nomandiae \& aliis titulis, teste R. de fluctibus in Apolog. contra Libavium."

205 See above, p. 145.

206 Mögling [Florentinus de Valentia], Rosa Florescens, Aviiv-Aiiir: "In Musica weiß man wol viel lieblicher melodey/ wo bleibt aber unter deß die rechte waare uhralte von Gott der Natur und allen dingen eingepflantzte hoch und wunderbahre consonanz unnd Musicalische Harmoni aller Creaturn/ darauß der Syn. \& Antipathia erlernt unnd viel unglaubiger sachen mögen verrichtet werden." On the musica universalis, see: Proust, "The Harmony of the Spheres from Pythagoras to Voyager," $35^{8-367}$. On Fludd and musical harmony, see: Godwin, The Harmony of the Spheres.

207 Mögling [Florentinus de Valentia], Rosa Florescens, Aviv-Aviir: "Das Menapius ferner schleust/ die Brüderschafft vom Rosen Creutz veracht und vernichtige alle Vniversiteten, Academias, gelehrte Doctores und Magistros, weil sie gesagt/ das alle Künstler höchlich 
and wanted their reformation, not their abolition. His criticism of the traditional sciences in fact mirrored Fludd's: Mögling claimed also that the impressive recent inventions in the arts and sciences were not found at universities, where scholars were too busy repeating what had been studied before, discussing medieval quaestiones, and disputing each others' philosophies. Scholars, he observed, debated "from doubtful questions an entire day purely on logical grounds, without regard of the things themselves, in the end they know more of the same than before." ${ }^{208}$ For Mögling, Grick belonged to those stubborn scholars who were proud of their practice of disputation and of their eloquence with languages:

That [Grick] conceives that it all is settled with Latin, French, Italian, Spanish, English, Bohemian, Hungarian, Polish, High and Low German, Greek or similarly different languages, as also with useless contentious disputations in the sciences and arts, and that this would be sufficient is a vain imagination, and a deception that has taken root long ago in the majority. 209

Such displays of eloquence would neither improve nor perfect the arts, nor bring about knowledge of things yet to be discovered. It was for this reason that the brethren's aims were so far removed from the academic playground of scholastic eloquence: "The fraternity itself acknowledges that it attaches greater respect to the realities of nature, than to the daintiness of many tongues," which were "nothing more than merely tokens and shadows of things." 210 The contemporary sciences were anything but perfect, with much still to be done in astronomy, astrology, physics, ethics, and politics; and many

laboriren und biß anno 1615. im verborgen gelegen/ ist zu jehe geurtheilt/ unnd wird sich in ihren schrifften das widerspiel erweissen."

208 Ibid., Aiiir: "wir aber nehmens weinig in acht/ und ist der Gelehrten gröste kunst/ von zweyfligen quaestionibus ein ganzen tag sein purè putè Logicè ohne betrachtung der sachen selber zu discurirn, quo finito, item plerumque norunt, quod ante."

209 Ibid., Aiiir: "Das er gedenckt es sey mit Lateinischer/ Französischer/Italienischer/ Spannischer/ Englischer/ Bömischer/ Ungerischer/ Polnischer/ hoch und nider Teutscher/ Grichischer/ oder dergleichen unterschiedlichen sprachen/ wie dann auch mit unnötigen zänckischen disputirn in scientiis \& artibus verricht/ und sey den sache gnug gethan/ ist ein eitele imagination, und lange zeit hero bey mehrertheils eingewurzelter betrug."

210 Ibid., Aiiir: "Die Fraternitet bekennt selber/ das sie ihnen die Realia naturae mehr und höher lassen angelegen sein/ als zierlichkeit vilerhand zungen und billich/ sintemal selbige mehrers nit als blosse notitiae \& umbrae rerum." 
of the cures prescribed in medicine did not work. ${ }^{211}$ It was this state of affairs that prompted Mögling to ask:

Do we not need a reparation, then? Should not the dilapidated temple of Pallas be rebuilt? 'No,' says Menapius, 'not through such unnatural means.' Whence does he know this? Who has told him that the promises of the brethren are against God and nature, while even he himself acknowledges that there is still much hidden in nature?212

In Mögling's eyes, the Rosicrucian reformation entailed a study of the natural world. Instead of perpetuating the universities' stale practices, the Rosicrucians investigated nature directly. They aimed to restore the once thriving studies and to complement these by new investigations. New things were being discovered every day, according to Mögling, which were neglected in academia but by which the old sciences could be improved. ${ }^{213}$ Academics wanted to be "erudite heads," but according to Mögling they should be investigating matters by their hands and eyes. ${ }^{214} \mathrm{He}$ raised the status of manual skills as opposed to Grick's humanist inclinations. Like Fludd, he wished to complement the Book of Scripture by the Book of Nature. Paracelsus had shown the way, replacing scholarly writings by the study of nature itself. For this, Grick had called him a "sewer of Satan," but in Mögling's estimation his was instead an example worth following, as he taught that the highest wisdom was found in nature. ${ }^{215}$

211 Ibid., Aviiiv $-B^{\mathrm{r}}$.

212 Ibid., Aviiiv-Br: "Soll dann nicht einer reparation betreffen? Solt nicht das ein gefallne Templum Palladis wider erbaut werden? Nein spricht Menapius, durch solche wider Natürliche mittel nicht. Woher weiß er das? Wer hat ihm gesagt/ das die promissiones Fratrum Gott unnd der Natur zu wider/ da er doch selbst bekennet/ es sey in der Natur noch viel verborgen."

213 Ibid., Aviiiv: "Wir sehen täglich/ kommen neue ding herfür/ daran man zuvor nie gedacht/ oder werden doch die alten verbessert."

214 Ibid., Aiiiir-Aiiiv: "Sie sehen auff die Terminos und lassen die res, nehmen den schatten für die Wandt/ wollen dennoch physici, Naturkündiger und hochgelehrte köpff sein wann man aber solte zu werck schreitten unnd die sachen mit der hand/ also zu reden/ angreiffen \& ad oculum demonstriren [...]."

215 Ibid., Biiir: "Paracelsus in Secreto Magico schreibt/ die Heydnische Scripta, so den grund oder Richtscheid der natur nicht vermögen/ sollen zu nichts geachtet/ sondern Vulcanobefohlen werden/ und dagegen das höchste Buch Sapientia, welches von dem einigen Geist Gottes außgehet/ auß dem centro der Natur gesucht werden [...]. Diß ist die meynung Theophrasti, der von Menapio vermessener weiß mancipium et cloaca sathanae genent wird/ da doch seine eigene Schrifften das contrarium è diametro beweisen unnd darthun." 
But the Rosicrucians did not merely turn from paper books to the Book of Nature. The study of the Book of Nature was intimately related to divine matters. For Paracelsus, Mögling explained, the study of this book had been inspired by God. ${ }^{216}$ Likewise, the Rosicrucians studied "the eternal sole true book of life, in which are hidden all art, science, and things [which seem] impossible to human reason. Because what is the physics, which does not take its footing from Scripture? Nothing."217

In parallel with the improvement of manual arts at the expense of scholastic practices, Mögling claimed that the Rosicrucians' second substitute to academic education was theosophy. In Flourishing Rose he returned once again to the issue of ergon and parergon, but the connection between the ergon and general reform is more clearly drawn here than it had been in the Mirror or the Pandora, the two tracts described in the previous chapter-presumably because the Flourishing Rose was a direct response to Grick, who challenged precisely this reform. Whereas in the other two texts, Mögling had first and foremost explained the distinction between ergon and parergon, in his Flourishing Rose he clarified the way in which the Rosicrucian ergon contributed to the improvement of the sciences: the study of the Supreme Being was the Rosicrucian alternative to established sciences and could educate people in all matters. He linked the study of nature with theosophy:

Who understands the great Book of Nature with its signs and characters impressed by God, considers the universal spirit of the world, contemplates the origin and continuation of all creatures in eager fear of God, considers his own ability, like all wisdom, nay God Himself in him, will certainly find such things as Menapius deems impossible. ${ }^{218}$

216 Ibid., Biiir, Biiiir. Cf. above, pp. 143-144.

217 Ibid., Biiv-Biiir: "[Die fratres] sehen mit den augen deß verstandts purè patientes, in das Ewige Einige Waare Buch des Lebens/darin alle künst/ wissenschafft und vor Menschlicher vernunfft unmögliche sachen verborgen. Dann was ist die Physica, die nit auß der Schrifft ihrer fuß nimbt? Nichts." This may remind us of Weigel's distinction between "fleish," "vernunfft," and "verstand," which he connected to three sets of eyes; see: Weigel, Gnothi seauton, 24.

218 Mögling [Florentinus de Valentia], Rosa Florescens, Bv: "Wer Magnum librum Naturae mit seinen von Gott imprimirten signaculis unnd Characteribus verstehet/ den Spiritum Mundi Universalem zugemüt führet/ den ursprung unnd continuation aller Creaturn in eyfferiger furcht Gottes contemplirt, sein eigen vermögen/ wie alle Weißheit/ ja Gott selbst in ihm betracht/ wird gewiß finden solches/ das Menapius vor unmöglich acht." 
Perfection of knowledge was what Menapius (Grick) had deemed unobtainable, but this perfection had, Mögling argued, now become possible thanks to the brethren. Humans could understand the world's origin and that of all its creatures, therefore being able to see into the invisible reality of the world, according to the theosophical notion that the divine could be understood through a study of nature. But God could also be studied in the microcosm, as Mögling had explained earlier; ${ }^{219}$ and conversely, "[t]he human being can have and understand everything through God, who lives within him." Humans did not require the books of scholars; paper books were mere memorials through which humans may remember what is within them. ${ }^{220}$ Besides the Book of Nature, there was a need for a new, different book, to teach humans everything scholarly writings could not. This was the book that resided within humans, although few were capable of reading it. ${ }^{221}$ Mögling called it the "Book of Life, which is inscribed with the finger of God in all human hearts."222 The Book of Scripture and the Book of Nature were complemented by the Book within, and in any of these three types of books God could be studied.

To study the Book of Life "is the ergon of the brethren," "the highest science, which they call pansophia." ${ }^{223}$ Mögling explained that this Book of Life

is the life of all human beings, and it is the light of humans, which it kindles in the darkness, it is the Word of God [...]. The Word is God's

219 See above, p. $280 \mathrm{ff}$.

220 Mögling [Florentinus de Valentia], Rosa Florescens, Bviiir: "Alles kan der Mensch/ vermittelst Gott/ der in ihm wohnt haben und verstehen/ von unnd auß sich selbst die Büchen (wie eine gelehret Mann schreibt) seind nichts anders als memorial, oder Zeugschrifften/ dadurch wir erinnert und überzeugt werden/ dessen das in uns ist [...]."

221 Ibid., Bviiiv-C ${ }^{\text {r: }}$ "Alle Bücher der Welt kanstu lernen ohn sonderbahre mühe auß einem einigen Buch/ und diß Buch ist in dir/ und in allen Menschen inn grossen und kleinen/ in jungen unnd alten/ inn gelehrten und ungelehrten/ Aber gar wenig/ ja freylich gar wenig können dasselbige lesen."

222 Ibid., Cr: "Ja viel hochgelehrte dürffens in ihnen verlaugnen/ kleben also am todten Buchstaben/ der da ausser ihnen ist/ und verlassen das Buch deß lebens/ das doch mit dem finger Gottes eingeschrieben ist/ in aller Menschen hertzen."

223 Ibid., $\mathrm{C}^{\mathrm{v}}$-Ciir: "Und dieses ist das Ergon Fratrum, das vorwerck Regnum Dei unnd die höchste wissenschafft/ von ihnen genand Pansophia." Cf. Mögling [Florentinus de Valentia], Rosa Florescens, $\mathrm{C}^{\mathrm{v}}$ : "Diß ist das Buch deß lebens/ der Geist die weißheit/ ja Gott und sein Reich selber in Menschen/ dannenhero Lucae 17: Das Reich gottes kompt nicht mit eusserlichen gebärden/ denn sehet/ das Reich ist innwendig in euch Item 1 Corinth. 4. Das Reich Gotes siehet nicht in worten/ sondern in der Krafft." 
wisdom within humans, it is God's image in humans, it is God's spirit or finger in humans, it is God's seed or law, [it is] Christ, God's kingdom and all in all. ${ }^{224}$

With these notions, Mögling clearly drew on Valentin Weigel, and particularly on the final chapters of Weigel's The Golden Grasp (1578). In that work, Weigel had explained that humans have two sets of eyes, and accordingly two types of knowledge. One type of knowledge is natural and comes from the external world, the other type is supernatural and comes from God, who resides within humans. Like Mögling, Weigel also argued that paper books were merely written testimonials of what was contained already within human beings. ${ }^{225} \mathrm{He}$ called the inner book the Book of Life, and Mögling's passage about the Book of Life was verbatim the same as a passage from Weigel's text: The Book of Life

is the life of all human beings, and it is the light of humans, which it kindles in the darkness, it is the Word of God [...]. The Word is God's wisdom within humans, it is God's image in humans, it is God's spirit or finger in humans, it is God's seed, God's law, [it is] Christ, God's kingdom [...].226

For Mögling, continuing in Weigel's footsteps, this internal divine book was the "treasure of the new birth," which he claimed, echoing Weigel, was "sweeter than honey and virgin honey."227 Mögling advised Grick to study this book, which would bring him more wisdom than reading paper books and understanding many languages. ${ }^{228}$

224 Ibid., Ciir: "Es ist das leben aller Menschen/ unnd ist das liecht der Menschen/ welches sie erleuchtet inn der finsternuß/ es ist Gottes wort [...]. Das wort ist die Weißheit Gottes in Menschen/ es ist die Bildnuß Gottes im Menschen/ es ist die Geist oder finger Gottes im Menschen/ est ist der Sam oder Gesetz Gottes/ Christus/ Gottes Reich und alles in allem."

225 Weigel, Der Güldene Griff, ch. xvi.

226 Ibid., Der Güldene Griff, $\mathrm{K}_{4}^{\text {r: }}$ "[...] Es ist das Leben aller Menschen, und ist das Liecht der Menschen, welchs sei erleuchtet in der Finsternis/ es ist Gottes Wort [...]. Das Wort ist die Weißheit Gottes im Menschen/ est ist die Bildniß Gottes im Menschen/ es ist der Geist oder Finger GOTtes in Menschen/ es ist der Same Gottes/ das Gesetz Gottes, Christus Gottes Reich." Weigel explained that he drew on Wisdom 7 and 8.

227 Mögling [Florentinus de Valentia], Rosa Florescens, Ciiv: "Also auch verhindert ein kurtze schnöde lust der Welt/ den ewigen unendlichen Schatz der neuen geburt/ die da süsser denn Hönig und Hönigsaim." Cf. Weigel, Der Güldene Griff, Liir - Liiv: "Also auch verhindert eine kurtze Schnöde Lust der Welt/ den Ewigen vnendtlichen Schatz der Newengeburt/ die da süsser dann Honig vnd Honigsaum." Cf. also ibid., ch. xv.

228 Mögling [Florentinus de Valentia], Rosa Florescens, Ciiir: "Betrachst lieber Bruder Menapi, ob deiner Frag und instans hiemit ein genügen geschehen. Ich weiß/ und wil dir 
Knowledge of the Book of Life was linked with the new birth, the birth of Christ within humans. To be born again, according to John 3, means to be born in the spirit and to be able to enter God's eternal kingdom. Humans, for Mögling, can internally be reborn in Christ and enter God's realm within, from which they may acquire complete knowledge in this life. This was what the Rosicrucians had in mind, because "[t]he brethren urge [others] first to search for the kingdom of God, and they desire the new birth in Christ." 229 Complete wisdom was Christian wisdom, the study of nature a Christian endeavour, and "to know God and all creatures, is the highest perfection of a human."230

Mögling's views also had apocalyptic connotations. He linked the new birth and the kingdom of God to earthly perfection, which was to be acquired before the end. Because understanding the chronology of worldly matters implied insight into divine secrets, Mögling once again turned to Scripture. The Rosicrucians had not done so, but Grick, when attacking them for their promise of future earthly perfection, had. Mögling now also pointedly referred to the Bible in order to carefully argue against Grick's views. Grick, Mögling recalled, had asked how the brethren knew that everything will come to perfection before the end of the world. To prove the opposite, Grick had referred to Isaiah, who foretold that the end of the world would be characterised by destruction and distress. ${ }^{231}$ Mögling seems not to have wanted to be so heretical as to contradict Scripture, and argued that this passage was not at odds with Rosicrucian promises of perfect knowledge on earth. According to him, Grick attributed claims to the Rosicrucians that did not have their origin in the manifestos. ${ }^{232}$ He granted that Isaiah prophesied about future destruction, and that the Fama stated that

vergwisen/ heiligestu Gott nur etlicher solcher Sabbath/ unnd list inn diesen Buch mit den augen deß Geistlichen verstandes/ du wirst mehr/ sowol inn Göttlich als Creatürlichen sachen außrichten/ auch weiser unnd gelehrter seyn/ als wann du aller Philosophorum, Poëtarum, Oratorum, oder Grammaticorum schriffen gelesen/ ja viel hundert Sprachen könnest die so vorschüblich nicht seyn/ als ein einiger solcher Sabbath/so er von rechtem Herzen/ unnd nicht auß heucheley gehalten wird [...] Thust du das/ so bistu Gott angenem/ dem Nechsten nützlich/ und ein waaren RosenCreutzer/ (die du doch so unschultig für Teuffle achtest) [...]."

229 Ibid., Biiv: "[...] da sie das quaerite primo regnum dei, urgiren, und die widergeburt in Christo begeren [...]."

230 Ibid., Ciir: "Gott und alle Creaturn erkennen/ ist summa hominis perfectio."

231 Ibid., Bviv-Bviir ${ }^{r}$. Here Mögling cites Grick verbatim; see: Grick [Menapius], Copia literarum, $\mathrm{C}^{\mathrm{r}}$.

232 Mögling [Florentinus de Valentia], Rosa Florescens, Bviir: "Auff solche instantiam kürzlich zu antworten. Möcht ich wol wissen/ wannenhero Menapius diese quaestion formirt, sintemal kein RosenCreutzer niemals solchs gesagt/ und hat author entweder ihre- 
before the end of the world God will grant to the world the return of the truth, light, and dignity that Adam had lost. ${ }^{233}$ But this perfection, he explained, will not be granted to all, but only to some people in the world. ${ }^{234}$ This means that both this truth and light as well as the destruction prophesied by Isaiah may be expected: "The world is too bad, and bad and good will be found until the end, thus the saying of Isaiah remains intact. Thus God's terrifying unforeseen future remains, although for some Godfearing people the treasures of wisdom will be uncovered."235 Mögling's solution to the by now familiar issue of the possible return of perfection to earth was unique: there will be both good and bad until the Final Day, because some few will be allowed to reach perfection in this life. He referred to Joel 2:28-32, which had also been invoked by Fludd, to confirm his reading of Isaiah. Joel prophesied the illumination of some, and of terrible signs on earth. ${ }^{236}$ For the future, Mögling argued, we may indeed expect disasters, but some will be granted complete illumination: "Here you see explicitly, good-hearted reader, how both, one being the prevention of the other, may be true at once, namely the terrifying wonders and the illumination of the faithful."237

meinung nicht recht verstanden/ oder den sensum auß mißgunst corrumpirt, wer hat jemals gedacht/ das wir in diesem leben alle werden gleich werden?"

233 Ibid., Bviir-Bviiv: "Author Famae schreibt: Gott hat gewiß beschlossen/ der Welt vor ihrem untergang welcher bald hernacht folgen soll/ noch eben solche warheit/ liecht und herrlichkeit/ widerfahren zulassen unnd zugeben/ wie der erst Mensch Adam im Paradiß verscherzt unnd verloren hat?"

234 Ibid., Bviiv: "Der Welt/ spricht er [author Famae]/ nicht aber allen Menschen/ sintemal in einem andern er die Geldbegirigen excludirt."

235 Ibid., Bviiv: "Die Welt ist zu arg/ unnd werden böß unnd gut biß ans end erfunden/ geht auch darumb dem spruch Esaie nichts ab. Dann Gottes erschröckliche unversehene Zukunfft bleibt/ ob gleich etlichen Gottsfürchtigen Menschen die schätz der Weißheit entdeckt."

236 Ibid., Bvii - Bviiir. Joel 2:28-32: "And it shall come to pass afterward, that I will pour out my spirit upon all flesh; and your sons and your daughters shall prophesy, your old men shall dream dreams, your young men shall see visions. And also upon the servants and upon the handsmaids in those days will I pour out my spirit. And I will shew wonders in the heavens and in the earth, blood, and fire, and pillars of smoke. The sun shall be turned into darkness, and the moon into blood, before the great and terrible day of the Lord come. And it shall come to pass, that whosoever shall call on the name of the Lord shall be delivered: for in mount Zion and in Jerusalem shall be deliverance, as the Lord hath said, and in the remnant whom the Lord shall call."

237 Mögling [Florentinus de Valentia], Rosa Florescens, Bviiiv: "Hie sihestu außdrücklich guthertziger Leser/ wie beedes/ eins eine verhinderung deß andern/ die erschröckliche wunder unnd erleuchtigung der glaubigen möge beysammen sein." 
Perfect knowledge was still possible, but internally, while the external world was in distress, because human beings have the entire world within them:

And why should it not be possible that human beings arrive at such perfection still in this life, given that all arts, science, all creatures, heaven and earth, the entire world, yes God Himself is hidden within him? The human being can, by means of God, Who resides within him, have and understand everything. ${ }^{238}$

Mögling's belief in such future perfection was intimately related to the notion of Christ's atoning death:

[Adam's] sin has been atoned by Christ. If we now want to follow our Saviour, not oppose ourselves to God [...], and surrender ourselves to God the Lord entirely and completely as a pure home and habitation, He will certainly without restraint exercise His marvels in us, and He will remain in us, we in Him. ${ }^{239}$

The manifestos had not made an explicit link between the Redeemer and the human possibility of inner perfection, but Andreae was later to establish a similar connection between the possibility of inner perfection and Christ's crucifixion in his Christianopolis. ${ }^{240}$ This link enabled Mögling to maintain that only the pious and pure will acquire this beatific state on earth and enjoy God's presence and the state of Adam in Paradise within. ${ }^{241}$ By arguing in this way, he was doctrinally closer to Arndt and to the later Andreae than to the Rosicrucian manifestos. His solution resided in the notion that those gran-

238 Ibid., Bviiir : “Und warumb solts nicht möglich sein/ den Menschen zu solcher perfection noch in diesem leben zugelangen/ weil alle Künst/ Wissenschafft/ alle Creaturn/ Himmel und Erden die ganze Welt/ ja Gott selbst in ihme verborgen? Alles kan der Mensch/ vermittelst Gott/ der in ihm wohnt haben und verstehen."

239 Ibid., Ciiiv: "Adam hat seine Weißheit anderst nicht verlohrn/ als durch sein eigen willen. Nun ist sein Schuld gebüst durch Christum/ wann wir nun unserm Erlöser wollen nachfolgen/ uns Gott nicht widersetzen [...] unnd uns Gott dem Herrn ganz unnd gar zu einer reinen wohnung und habitaculo ergeben/ wird er gewiß ohne verhinderung seine Wunderwerck inn uns üben/ Er in uns/ wir in ihm in Ewigkeit verbleiben."

240 See above, p. 203.

241 Mögling [Florentinus de Valentia], Rosa Florescens, Ciiiv: "Und diß ist der Brüderschafft kurze beschriebene meynung/ biß zu anderer zeit/ nicht das alle Menschen sollen gleich werden/ dann der mehrertheil zu verstockt unnd Gottloß/ sondern das die glaubige/ die Gott ein reinen Sabbath halten/ werden sein wie Adam im Paradiß/ denn eben diß reine gewissen unnd ruhe in Christo ist das Paradeiß." 
ted such an internal "paradise" will learn, "in accordance with the Rosicrucian promise," in one book all arts of the world, and "know completely everything that is in the macrocosm and microcosm." ${ }^{242}$

Grick was concerned with earthly affairs rather than with paradisiacal inner perfection. As for Mögling, he did not neglect earthly problems, but saw them as solvable through manual arts and theosophical studies. The lack of visible reform of society by the brethren was central to Grick's attack, but Mögling swiftly dismissed his objections, focusing on the reform of knowledge instead. In Mögling's view, Grick belonged to that type of university scholar that had for long defined the course of academic learning, but had failed to contribute anything substantial. He saw the development of knowledge in a way substantially different from Grick: the latter inserted himself into the tradition of the humanists, whereas Mögling followed so-called Paracelsian novatores and artisans in their study of the natural world. That he also counted theosophy among the studies of the Rosicrucians was, at least in part, because he believed it could prepare one for the future life: society was not just to be transformed, while man himself could also live internally in paradise and acquire perfect wisdom. In his interpretation of the Rosicrucian manifestos, by drawing on Weigel Mögling placed these texts in the tradition of Weigelianism. Perhaps in an attempt to avoid charges of Pelagianism, he considered the enjoyment of paradise within only possible for the faithful few, but those few would have complete wisdom and arrive at perfection still in this life.

\subsection{Concluding Remarks and Further Challenges: Official Investigations}

The cases discussed in Chapter Four were concerned with the proposed alternative of the Rosicrucians to established studies more so than with their call for reform. The scholars discussed in this chapter, in turn, directly referred to the Rosicrucian general reformation. It is striking that while the Rosicrucian manifestos discussed religious, political, and scientific change, the debates analysed in this chapter revealed concerns for exactly these fields. All four authors addressed the Rosicrucian intention to reform the academies as well

242 Ibid., Ciiiir: "Fürwar wer in diesem Paradiß ist/ der wird/ laut Rosencreuzischer promission $[\ldots]$ in einem Buch alle Künst der Welt feliciter erlernen [...], alles was in Macro\&Microcosmo völlig erkennen [...]." 
as the announcement of a future perfection. Evidently, the scholars contra the Rosicrucians rejected both notions, whereas the authors defending them argued in favour of them. Other elements of the call for general reformation were addressed in various ways and to various degrees. Libavius attacked the Rosicrucian reformative project from a Lutheran and academic perspective; Grick not only as an academic but also as a citizen, when discussing societal or political reform. He relished the idea of the improvement of cities that were now in a state of decay and the support of people who were suffering, but he was taken aback by the lack of support coming from the Rosicrucians. According to Libavius, the Rosicrucians distorted the Bible; according to Libavius and Grick, they misled the people and planned to corrupt the sciences and arts; and both Libavius and Grick rejected the Rosicrucian alternative, which to them represented magical Paracelsian fantasies.

In his response, Fludd undermined Libavius' Lutheranism as well as his defence of academic practices; whereas Mögling coupled the reformation of society and the arts with the reform of humans and the divine, and situated the divine in the internal human being. Mögling and Fludd further believed that the brethren had access to God through nature. As we have seen in the previous chapter, because the Rosicrucians had not clearly formulated their alternative to established learning, this alternative was subject to a variety of interpretations, in correspondence to the different worldviews of their readers. This is also where Fludd and Mögling parted ways: Fludd viewed the Rosicrucians as restoring ancient and divine magic, whereas Mögling believed them to complement technological arts by theosophical studies conducted through God and the Book of Life within themselves - that reform was required seemed evident to both, but they differed over the ways in which the reforms should develop.

Similar tensions emerged in many of the early investigations conducted at courts and universities into authors suspected of Rosicrucianism. The Rosicrucian furore had quickly spread throughout Europe, and Rosicrucianism found advocates amongst individuals with often fairly disparate beliefs. Some authors mixed Rosicrucian ideas with other traditions, so that soon the heterodox movement became even more difficult to comprehend by traditional academics, rulers, and orthodox theologians. Institutions were at a loss as to how to interpret this phenomenon, and they investigated members suspected of Rosicrucianism in order to assess the danger they posed to religion, politics, and knowledge. Some of these investigations have been discussed in the available literature, but they deserve some attention here because they provide a good characterisation of the reasons not only of individuals but also of institutions for their condemnation of figures with Rosicrucian sympathies. 
In some cases, investigators were doing their utmost to protect academic conventions. 1619 witnessed the prosecution of two heterodox Weigelian thinkers at the Calvinist University of Marburg, which was under the supervision of the Calvinist Landgrave Moritz von Hesse-Kassel (1572-1632). There, Philipp Homagius (whose father-in-law, Wilhelm Wessel, was the printer of the Fama and Confessio in Kassel) and Georg Zimmermann were investigated for their heterodox ideas and suspected of Rosicrucianism. ${ }^{243}$ In December 1619, Homagius and Zimmermann had thrown academic writings out the window of the Calvinist university, among which were works by Virgil and Cicero, as well as Greek and Latin lexicons. This radical action was seen as an affront to established learning, prompting the university theologians to investigate the two scholars. When questioned, they argued that universities and their programmes should be changed, and that the study of Aristotle and languages should be replaced by "modern institutions." ${ }^{244}$ Landgrave Moritz was warned about the two scholars, their books were investigated, and they were suspected of Weigelian enthusiasm. ${ }^{245}$ When interrogated at the order of Moritz, they were questioned about the writings of Paracelsus and Weigel, but notably also about the Rosicrucians-Paracelsianism, Weigelianism, and Rosicrucianism seemed equally heterodox, and the investigators believed that their proposed reform of education must have been informed by these divergent yet overlapping movements. In response, both Homagius and Zimmermann praised the fraternity and its brethren. ${ }^{246}$ Under interrogation, Homagius was asked about his intentions, whether Rosicrucians had assembled in Marburg, and to whom the Rosicrucian lion referred. This last question is interesting, because by this time, December 1619, at the inception of the Thirty Years' War, the Protestant Prince Frederick v of the Palatinate had just been crowned King of Bohemia and was portrayed by some as the Lion of the North.

The otherwise little-known Johannes Cäsar, who had been associated with Homagius, was also questioned about the fraternity, his opinion of it, and his acquaintance with its members. He was further asked about his views concerning the announced Rosicrucian reformation and how that reformation was to be understood: spiritually or secularly. ${ }^{247}$

\footnotetext{
243 Hochhuth, "Mittheilungen" (1862), 86-159; Moran, "Paracelsus, Religion and Dissent: The Case of Phillip Homagius and Georg Zimmermann," 65-79.

244 Hochhuth, "Mittheilungen" (1862), 87-92.

245 Ibid., 102.

246 Ibid., 117, 120; Moran, "Paracelsus, Religion, and Dissent," 69.

247 Moran, "Paracelsus, Religion, and Dissent," 73-74.
} 
It is unclear whether the defenestration of these academic writings by the two rebellious Marburg academics was motivated by Rosicrucian sympathies, but the investigators immediately saw in this act an association with intangible, heterodox movements like Rosicrucianism. What began as an attempt to reform the university, which by itself was not specifically Rosicrucian, was quickly interpreted as being related to Rosicrucian reform sympathies.

The Marburg investigators, like Libavius, were also worried about questions of religious orthodoxy. They interrogated Homagius and Zimmermann on the sacraments, rebirth, free will, law, predestination, Mary, and their millenarian views - all topics on which Calvinism had established views. ${ }^{248}$ The manifestos had not discussed any of these themes apart from millenarian views, but the investigators interrogated Homagius and Zimmermann on matters that could determine their alignment with any confession. Landgrave Moritz was clearly worried about the influence of these men, and believed that they could exercise a corrupting influence over many pious hearts. ${ }^{249} \mathrm{His}$ involvement in the matter is striking, given the fact that the Fama could only have been published in his territory with his explicit consent. ${ }^{250}$ Under interrogation, Zimmermann recanted his reformative views on university practice but, according to the Marburg report, Homagius answered his interrogators by praising Rosicrucianism and linking it to Paracelsian and Weigelian notions. Thus, in answers to questions about religious orthodoxy, topics unrelated to Rosicrucianism came to be associated with the movement. Homagius was tortured and sentenced to lifelong imprisonment in Königsberg (Biebertal) by order of Moritz, but was helped to escape to Giessen by professors of that city who took pity on his situation. ${ }^{251}$ The Marburg episode, in any case, shows how Rosicrucianism came to be linked to views antithetical to Calvinist academic and religious life.

After having fled to Giessen, Homagius became subject of another investigation, this time under the name of "Johannes Homagius." The investigation in Giessen shows that also Lutheran theologians felt threatened for religious reasons by subversive groups like the Rosicrucians. Theologians of the Lutheran university of Giessen investigated Homagius and the physician Heinrich Nolle (Nollius). No sooner had they begun their investigation than Homagius

\footnotetext{
248 Hochhuth, "Mittheilungen" (1862), 102, 114-115, 118-119; Moran, "Paracelsus, Religion, and Dissent," 68.

249 Hochhuth, "Mittheilungen" (1862), 123.

25 O Gilly, "Theophrastia Sancta," 182 esp. n. 71; idem, "Die Rosenkreuzer," 23-24; Tilton, "The Rosicrucian Manifestos and Early Rosicrucianism," 138.

251 Klenk, "Ein sogenannter Inquisitionsproceß in Gießen anno 1623," 45-47.
} 
fled the city for safer havens. ${ }^{252}$ Nolle, his thought associated with that of Hermeticism and Paracelsianism, had written a Mirror of the Philosophical Parergon, published in Giessen, 1623, which was what prompted the orthodox members of the university of Giessen to investigate him. ${ }^{253}$ The text was an alchemical-allegorical story, inspired by the Chemical Wedding, in which Nolle acclaimed Hermes and Paracelsus as his authorities. He also openly and repeatedly expressed his hope for the Rosicrucians' general reformation of the sciences. ${ }^{254}$ The investigators of the Faculty of Theology considered Nolle's Mirror to be dangerous because it underminded the true faith, ${ }^{255}$ and their report listed several points of the Mirror that they considered suspicious specifically for religious and, by implication, confessional reasons. ${ }^{256}$

The Lutheran theologians communicated their findings to the Lutheran Landgrave Ludwig $\mathrm{V}$ of Hesse-Darmstadt (1577-1626). Ludwig decreed that Homagius and Nolle were to be "put in prison, so that no one could come to them, not even writings could be delivered to them," ${ }^{257}$ and he ordered that Nolle's Mirror in all its editions be confiscated and that its printer be interrogated. ${ }^{258} \mathrm{He}$ further deemed Nolle to belong to a "certain sect," presumably the Rosicrucian society, and ordered an investigation into whether its members held meetings, where, when, and how often these meetings took place, and about what they communicated. All persons involved should be prohibited from any further spoken or written communication. ${ }^{259}$

252 Ibid., 45-47.

253 On Nolle, see for example: Hochhuth, "Mittheilungen aus der Protestantischen SectenGeschichte in der hessischen Kirche. Vierte Abtheilung: Die Weigelianer und Rosenkreuzer. Grunius und Nollius”; Gilly, "Das Bekenntnis zur Gnosis von Paracelsus bis auf die Schüler Jacob Böhmes"; Meier-Oeser, "Henricus Nollius (ca. 1583-1626). Aristotelische Metaphysik und hermetische Naturphilosophie im frühen 17. Jahrhundert." On Nolle's ideas, see: Hochhuth, "Mittheilungen" (1863), 192-215; Gilly, "Das Bekenntnis zur Gnosis," 422-423; Meier-Oeser, "Henricus Nollius."

254 Nolle, Parergi philosophici speculum; Kühlmann and Telle, CP, nr. 170, 1244.

255 Hochhuth, "Mittheilungen" (1863), 118; Klenk, "Ein sogenannter Inquisitionsproceß in Gießen anno 1623," 49-52.

256 Kühlmann and Telle, $c P$, nr. 170, 1249.

257 Report of Ludwig von Hesse-Darmstadt, 12 January 1623: "Und weil gute Aufsicht und exemplarischer Proceß in diesen ärgerlichen Dingen nöthig, sollt ihr Beide, homagium und Nollium unserem Hauptmann liefern, daß er sie an sichere Orte und eine Jeden absonderlich in's gefängniß lege, daß Niemand zu ihnen kommen, auch kein Schreiben beigestoßen werde," cited in: Kühlmann and Telle, $C P$, nr. 170, 1246.

258 Kühlmann and Telle, $C P$, nr. 170, 1245.

259 Report of Ludwig von Hesse-Darmstadt, 12 January, 1623, cited in: Kühlmann and Telle, $C P$, nr. 170, 1247-1248. 
Unlike the Marburg investigators, Ludwig did not refer to the Rosicrucians by name, but the suspected existence of a new heterodoxy was causing much disquiet in Giessen. Clearly, Ludwig, like Moritz, feared that unorthodox ideas would spread widely, corrupting others. Nolle must have understood what Ludwig implied, because under questioning he defended himself from any suspicion of Rosicrucianism. Also the faculties of philosophy and law, defending Nolle, distanced themselves from heretics, Rosicrucians, and Weigelians alike, which suggests that they felt that the revelation of involvement with any of these sects was the real purpose for these investigations. ${ }^{260}$ Ultimately, Nolle was indicted for his Rosicrucianism and Weigelian enthusiasm ("Schwärmerei"), as well as for meeting like-minded people. ${ }^{261}$

Similar yet more explicit fears of Rosicrucianism existed in the Dutch provinces. In June 1625 , the courts of Holland, Zeeland, and Friesland sent a letter to the city council of Haarlem that warned about "some persons who were named brothers of the Rose Cross who had taken their home in the city of Paris in France, [and who] have now also come to these provinces [...]."262 The reference to Paris was perhaps to the city's 1623 episode that also involved Descartes. The letter by the courts explained that the "sect" already held "meetings" "by night and at outrageous hours" "here in this land and, among other places, also within Haarlem [...]."263 Earlier, the Court of Holland had sent several unnamed works to Calvinist theologians in Leiden for investigation into the "Rosicrucian sect" and its "origin" and "teachings." 264 As was mentioned in the Introduction,

26o Hochhuth, "Mittheilungen" (1863), 223-227.

261 Kühlmann and Telle, $C P$, nr. 170, 1244; Meier-Oeser, "Henricus Nollius," 175.

262 Letter from the president and councils of Holland, Zeeland, and Friesland to the city council of Haarlem, dated 19 June 1625: "Also wij eenen tijt geleden verstaen hebben ende bericht zyn, dat sekere personen die hen noemen Broeders van den Roosen Cruce haer woonplaetse genomen hebben binnen de Stadt van Parijs in Vranckryck nu oock gecommen souden zyn in dese Provincien [...]," cited in: Bredius, Johannes Torrentius, 17. On the Paris episode, see: Kahn, "The Rosicrucian Hoax in France," 235-344.

263 Letter from the president and councils of Holland, Zeeland, and Friesland to the city council of Haarlem, dated 19 June 1625: "Ende wy, verstaen dat dickwijls, oock by nacht en ontyden die van de voorsz. seckte haer vergaderingen houden op verscheidenen plaetsen hier te lande ende onder anderen mede binnen Haerlem [...]," cited in: Bredius, Johannes Torrentius, 18.

264 Ibid.: "[...] gelyck wy oock becommen hebben verscheidene boucken ende geschriften inhoudende den oorspronck, t'gevoelen ende handel van die van de voorsz. secte den Roose Cruce, deweleke wij door een Commissaris daertoe gedeputeert hebben gedaen communiceren de Heeren Professoren in de Theologie tot Leijden ten ynde zijluiden naer behoorlycke examinatie ons daerop zouden dienen van haren advyse," cited in: Bredius, Johannes Torrentius, 18. 
on the basis of these works the theologians concluded that the Rosicrucian "sect" was an

error in doctrine [...], possessed, superstitious and magical; in her philosophy she is a fabrication of an erratic mind and a monstrous spirit, vain, useless, and filled with deceit; lastly rebellious towards the state $\left[\ldots . .{ }^{265}\right.$

These theologians believed that Rosicrucianism posed a threat not only to their confession, but also to philosophy and to political stability more broadly. They further claimed that the Fama's depiction of Christian Rosencreutz and the healthy and long life of the brethren was "against the law of illness and death, both imposed by God to all humanity for its sinfulness, and all those things are unusual, unheard of, and beyond the boundaries of human nature" - that is, against their Calvinist confessional views. ${ }^{266}$ After all, Adam's sin had made humans mortal, and now Rosencreutz and the brethren are depicted as defying God's laws.

Details of the report by the Leiden professors were passed by the Court of Holland to the city council of Haarlem, warning them that one of Haarlem's inhabitants, the famous Dutch painter Johannes Symonsz van der Beek, known as Johannes Torrentius (1589-1644), was seen "to be one of the principal men

265 ARA Den Haag, Hof van Holland, nr. 4601, 1625-1626: "Judicium Facultatis Theologicae in Academia Leydensi de Secta Fraternitatis Roseae-Crucis," translated into Dutch and reproduced in: Snoek, De Rozenkruisers, 537-545, esp. p. 544, "dwaling in de leer [...], bezeten, bijgelovig, en magisch; in haar filosofie is ze een verzinsel van een labiel verstand en een gedrocht des geestes, ijdel, zinloos en vol van bedrog, tenslotte oproerig ten opzichte van de staat." On the report, see: Snoek, De Rozenkruisers, $176-179$. The report is signed by the following professors: Antonius Waleus, Acad. Prot $[\mathrm{em}] \mathrm{p}$ [or]e Rector, Johannes Polyander, Andreaes Rivetus, Antonius Thysius. Åkerman mistakenly refers to "Catholic professors": Åkerman, Rose Cross, 175 .

266 ARA Den Haag, Hof van Holland, nr. 46o1, 1625-1626: "Judicium Facultatis Theologicae in Academia Leydensi de Secta Fraternitatis Roseae-Crucis," translated into Dutch and reproduced in: Snoek, De Rozenkruisers, 541: "Vandaar ook dat ze over de stichter van de gemeenschap in herinnering brengen dat hij 106 jaar oud zijn ziel aan God heeft gegeven, op natuurlijke wijze, niet gedwongen door ziekte, welke hij nooit in zijn lichaam had gevoeld, maar geroepen door de Heilige geest, en dat gedurende 120 jaar zijn lichaam mooi, herkenbaar, ongeschonden en volledig onaangetast is gebleven. p. 20, 21. en dat de lichamen van de andere vaders van de secte vrij van pijn en ziekte zijn geweest, hoewel die toestand het moment van het verscheiden niet kon overschrijden. p. $13 \mathrm{Al}$ die zaken zijn strijdig met de onontkoombare wet van zowel ziekte als dood, beide opgelegd van Godswege aan de totale mensheid om haar zondigheid, en al die dingen zijn ongewoon, ongehoord en gaan de grenzen van de menselijke natuur te buiten." 
of this [Rosicrucian] sect."267 The Court of Holland ordered Haarlem to protect its city from Rosicrucians, and to submit a report soon. ${ }^{268}$ In 1627 , on the basis of the report by the Calvinist Leiden theologians and a letter from the Court of Holland, Torrentius was thoroughly interrogated, tortured, and eventually sentenced to death. His trial vividly indicates the perceived danger that Rosicrucianism was thought to pose to society.

Torrentius was an extraordinary painter. From the many works he painted, it seems that only one small drawing and one painting have survived, the "emblematic still life with flagon, glass, jug, and bridle."269 This painting has become known as the "mysterious masterpiece." It is on display at the Rijksmuseum Amsterdam and still puzzles all experts, because they do not understand how the painting was made and which materials were used: no brush strokes can be detected on the painting, and even after careful chemical analysis it is unclear what sort of paint was used - all of which contributes to the enigma of Torrentius. ${ }^{270}$ His qualities as a painter had not escaped his contemporaries, either. The polymath Constantijn Huygens (1596-1687), for example, revered the painter, and named Torrentius' still life paintings miraculous, although personally he considered Torrentius a cunning man..$^{271}$

The interrogation of Torrentius began with questions about Rosicrucianism. Torrentius was asked whether he belonged to the Rosicrucian sect, which he denied. He was further questioned about the members and intention of the Rosicrucian fraternity. ${ }^{272}$ The investigators also questioned witnesses, of whom

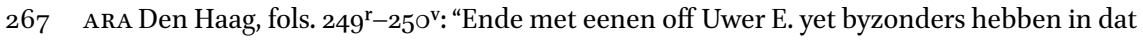
stuck jegens eenen Thorentius, die geseit wort wel eenen van de principaelsten ten wesen der voorsz. seckte," cited in: Snoek, De Rosenkruizers in Nederland, 111. On Torrentius, see: Bredius, Johannes Torrentius, Snoek, De Rozenkruisers, 105-168, 255-262, 282-289; Cerutti, De Schilder en Vrijdenker Torrentius.

268 Snoek, De Rozenkruisers, 112.

269 Torrentius wrote in the album amicorum of Gerard Thibault d' Anvers, in which he made a small drawing and a poem, and in that of Petrus Scriverius. A portrait of Torrentius can be found in the album amicorum of Joachim Morsius, see: Snoek, De Rozenkruisers, 154; Cerutti, De Schilder en Vrijdenker Torrentius, 114.

270 De Kroon, Mysterious Masterpiece (documentary, 2018).

271 Bredius, Johannes Torrentius, 4; Snoek, De Rozenkruisers, 132. The engraver Michel le Bron, who had written a pamphlet supporting the Rosicrucians, also commended Torrentius' skills as a painter; see: Bredius, Johannes Torrentius, 6 .

272 The questions were: "Off hy die spreeckt vande Broederschap ofte Ordre vande Rosencruyse es; Indien jaa, wat d'selve ordre meebrengt ofte inhoudt; Ende wie in de Provincie van Hollandt syn medebroeders ende medesusters syn, hoe genaempt ende waer woonachtig," cited in: Snoek, De Rozenkruisers, 117. On this trial, see: Bredius, Johannes Torrentius; Rehorst, Torrentius; Snoek, De Rozenkruisers, 105-168. Torrentius was visited in prison by famous painters, among whom Frans Hals: Bredius, Johannes Torrentius, $55^{-56}$. 
one clarified that he had stayed in a hostel near Torrentius and a company of Rosicrucians, thereby linking Torrentius to the apparently dangerous sect. Upon such suspicions, the investigators tortured Torrentius' close friend Christiaen Coppens, a wealthy merchant at whose house Torrentius had stayed for a while, and interrogated him about the Rosicrucians and Torrentius' connections to them - again revealing, as in Marburg and Giessen, the fear of subversive groups. ${ }^{273}$

The inquisitors soon turned to other matters which they considered equally suspicious. Torrentius was asked how he painted. He answered that he painted without brushes but with a "science" that created such a noise that it seemed as if a swarm of bees were flying over the painting 274 — not an answer that would have satisfied his interrogators. He was also questioned about religious matters: if he had wanted to form a (Rosicrucian) sect; whether he had argued that there was no God; what he thought about the Trinity and about Christ's suffering; and whether he had made offerings to the devil or had toasted the devil's health and wellbeing. Rosicrucianism seemed to represent an affront to confessionalism. Torrentius denied everything, but the city council's fear for the public life and wellbeing were amply demonstrated. ${ }^{275}$

Torrentius' views must have seemed so enigmatic and dangerous that he was brutally tortured during questioning. When he was asked "whether he had blasphemed against God," he denied, which, according to a report of the time, incurred the following treatment:

[T] hey put so many irons to each of his big toes that four servants could hardly tie him to a cord on his hands to wind him up to a torture rack [...] pulling apart arms, legs, and loins while [hot] waffle irons were screwed to his shin bones by the executioner [...]. After having fainted he was taken from the torture rack and put in a chair, and when he regained his consciousness, a mayor asked him: 'so, old chap, how are things now?' He answered: 'well, sir, only the body is a bit tortured.'276

273 Snoek, De Rozenkruisers, 157. Coppens was sentenced to five years solitary confinement and was banned from the city for seven more years for toasting the devil; see: ibid., 120 .

274 On this, see: Bredius, Johannes Torrentius, 7.

275 Bredius, Johannes Torrentius, 19, 34, 42-43, 46. Torrentius was also questioned on his visits to and behaviour towards women, accounts of which seem to have been subject to exaggerated misrepresentations; see: ibid., 21-24, 34-39.

276 City Library Rotterdam, Church of Remonstrants, cat. v. Hss. Nr. 197: “[...] wert wederom ingeroepen, ende sonder eenige vrage meer te doen wert geweijt men salt $\mathrm{u}$ wel doen bekennen, de dreijgement met de daet vergeselschapt, wert tumultuaire terstont niet tegenstaende sijn appel aent Hoff van Justitie, aende pleijt ende ter tortuere gebracht, 
Torrentius' torture was unusually cruel, yet he suffered without protest, so that even the executioners claimed to have felt compassion towards him. ${ }^{277}$ Ultimately, he became weak to the point of paralysis, and was unable to sign his own statement. ${ }^{278}$ Because the matter concerned blasphemy, torture seemed a means necessary and justified. ${ }^{279}$ The trial, however, was a sham: later interviews revealed that false statements against Torrentius had been created and supporting ones ignored. ${ }^{280}$ In 1628 , Torrentius was sentenced to be burned at the stake on charges related to "blasphemy," "impiety," and "harmful heresy."281 His presumed connection to the Rosicrucians was not mentioned in the verdict, despite the fact that this was what had prompted the investigation in the first place. ${ }^{282}$ This might be explained by the fact that, unlike blasphemy and heresy, Rosicucianism was not an offence or a crime. Torrentius' sentence, like his loathsome torture, was a remarkable and extraordinary measure even in his own time and place, and it was later changed to twenty years in prison. He was released two years later, in 1630, thanks to the intervention of the English King Charles I (16oo-1649), who was inspired by Torrentius' prodigious skills as a painter. ${ }^{283}$ The city council of Haarlem ordered that Torrentius' paintings

in dezer forme, men heeft hem soo veel ijsers aen elcke groote tee vast gemaeckt dat vier dienaers hem nauwelijcx met een coorde aende handen vast achter om over een latarolle hebben connen ophijsen, hebben hem soo een uijre lang laten hangen, armen beenen en lendenen, uit malcanderen gereckt, en middelertijt sijn hem wafelijsers (in de helle gesmeet of van helhonden gepractiseert en int werck gestelt) door de Beul op den schenen geschroeft, en soo dicht aengeset dat de Beul opt bevel van een (andere helsche Beul) die vast riep set aen set aen antwoorde, soo ick noch eens dichter aansette sullen de schinckels aen tween breken, [...]. [N]a flaeu geworden sijnde is hij afgenomen en in een stoel geset, en becomende soo vraechde hem een Burgemeester, ha Vogel hoe ist nu, hij antwoorde wel mijnheere alleenelijck het lichaem is wat germarteliseert en dat seijde hij met een groote sachtsinnicheijt na zijn ordinaris manieren," cited in: Snoek, De Rozenkruisers, 118119.

277 City Library Rotterdam, Church of Remonstrants, cat. v. Hss. Nr. 197: "Beul en diefleijders getuijgen datse haer leve dagen noijt niemant soo gepijnicht maer oock niemant die ijsselijcke pijne met sulcken patientie hebben sien doorstaen, al de woorden dien hij sprack waren bequaem en machtich om de conscientie te persen, als de ijsere schroeven sijn schenen deden, noijt een ongelaten woort quam uit sijnen monde, waer over beul en dienaers selfs hartelijcke compassie cregen," cited in: Snoek, De Rozenkruisers, 118-119.

278 Bredius, Johannes Torrentius, $46-52$.

279 Ibid., 45-46.

28o Ibid., 24-28, 39-40; Snoek, De Rozenkruisers, 114-115.

281 Bredius, Johannes Torrentius, 48-49. For the full report see: ibid.; Snoek, De Rozenkruisers, 121.

282 Snoek, De Rozenkruisers, 121.

283 Bredius, Johannes Torrentius, 49-64. 
in Haarlem be burned, so that today the only known surviving painting is his "emblematic still-life."

What is striking about all the cases mentioned here, is that the investigations and condemnations were initiated by Lutheran and Calvinist theologians, protecting, in the early years of the Thirty Years' War, their confession. Rosicrucianism was elusive, the ideas of its proponents, at least according to their inquisitors, were closely related to Paracelsianism and Weigelianism, and the movement seemed dangerous to the establishment. It is noteworthy that, for example in the case of Moritz, alchemical and magical studies were accepted. Moritz was very much involved in the investigation into Homagius and Zimmermann, and while he had been a patron to reformers of naturalphilosophical, medical, and alchemical studies, he was not so to unorthodox religious, Rosicrucian, and Weigelian endeavours, as is clear from the Marburg reports. ${ }^{284}$ In Giessen, Nolle was protected by professors of medicine, and Rosicrucianism was not first and foremost considered a danger in relation to medical, alchemical, and natural-philosophical ideas. Rather, it was especially its association with heterodox and radical religious views that was deemed suspicious. Even so, to the Marburg and Leiden theologians, Rosicrucianism also seemed to pose a threat to established learning and philosophy, for which reason they repudiated Rosicrucianism and the associated reformation also on academic grounds.

Equally remarkable is the fact that rulers were also involved in these investigations. In the case of Haslmayr, the Catholic Duke Maximilian III felt that the first responder to the Fama was a threat to stability. The Calvinist Landgrave Moritz and the Lutheran Landgrave Ludwig, as well as the representatives of the Dutch provinces, clearly intended to safeguard their respective lands and confessions. The political rulers from all three confessions felt threatened by the Rosicrucian manifestos and their followers. In particular the efforts by the Dutch provinces to defend political stability from this new 'sect' show the extent to which they considered the movement religiously, politically, and academically threatening.

The four authors discussed in this chapter, like the institutions mentioned, worried about the Rosicrucian reform plans and linked Rosicrucianism to other sects. Libavius and Grick associated it with Anabaptism; the investigators (and implicitly also Mögling) with Weigelianism; and Mögling, Libavius, Grick, as

284 On this, see also: Hochhuth, "Mittheilungen" (1862), 110-111, 121-123; Gilly, "Theophrastia sancta," $182-183 n 73$. This thesis runs against Moran's suggestion: Moran, The Alchemical World of the German Court, 93, 98-101, 128-129, who argues that Moritz supported Rosicrucians. 
well as the investigators also connected it to Paracelsianism. The individual criticisms of Libavius and Grick and the official warnings by investigators in Marburg, Giessen, and Leiden further indicate that Rosicrucianism was seen as a threat to Church, state, and knowledge — which was why Fludd and Mögling defended it. 